\title{
Green Space and Health Equity: A Systematic Review on the Potential of Green Space to Reduce Health Disparities
}

\author{
Alessandro Rigolon ${ }^{1, *(\mathbb{D})}$, Matthew H. E. M. Browning ${ }^{2} \mathbb{D}$, Olivia McAnirlin ${ }^{2} \mathbb{D}$ and Hyunseo (Violet) Yoon ${ }^{3}(\mathbb{D}$ \\ 1 Department of City and Metropolitan Planning, The University of Utah, Salt Lake City, UT 84112, USA \\ 2 Department of Parks, Recreation and Tourism Management, Clemson University, Clemson, SC 29634, USA; \\ mhb2@clemson.edu (M.H.E.M.B.); omcanir@g.clemson.edu (O.M.) \\ 3 Department of Recreation, Sport and Tourism, University of Illinois at Urbana-Champaign, Champaign, \\ IL 61820, USA; hyunseo2@illinois.edu \\ * Correspondence: alessandro.rigolon@utah.edu
}

Citation: Rigolon, A.; Browning, M.H.E.M.; McAnirlin, O.; Yoon, H. Green Space and Health Equity: A Systematic Review on the Potential of Green Space to Reduce Health Disparities. Int. J. Environ. Res. Public Health 2021, 18, 2563. https:// doi.org/10.3390/ijerph18052563

Academic Editor: Paul Tchounwou

Received: 9 February 2021

Accepted: 26 February 2021

Published: 4 March 2021

Publisher's Note: MDPI stays neutral with regard to jurisdictional claims in published maps and institutional affiliations.

Copyright: (c) 2021 by the authors. Licensee MDPI, Basel, Switzerland. This article is an open access article distributed under the terms and conditions of the Creative Commons Attribution (CC BY) license (https:// creativecommons.org/licenses/by/ $4.0 /)$.

\begin{abstract}
Disadvantaged groups worldwide, such as low-income and racially/ethnically minoritized people, experience worse health outcomes than more privileged groups, including wealthier and white people. Such health disparities are a major public health issue in several countries around the world. In this systematic review, we examine whether green space shows stronger associations with physical health for disadvantaged groups than for privileged groups. We hypothesize that disadvantaged groups have stronger protective effects from green space because of their greater dependency on proximate green space, as they tend to lack access to other health-promoting resources. We use the preferred reporting items for systematic reviews and meta-analyses (PRISMA) method and search five databases (CINAHL, Cochrane, PubMed, Scopus, and Web of Science) to look for articles that examine whether socioeconomic status (SES) or race/ethnicity modify the green spacehealth associations. Based on this search, we identify 90 articles meeting our inclusion criteria. We find lower-SES people show more beneficial effects than affluent people, particularly when concerning public green spaces/parks rather than green land covers/greenness. Studies in Europe show stronger protective effects for lower-SES people versus higher-SES people than do studies in North America. We find no notable differences in the protective effects of green space between racial/ethnic groups. Collectively, these results suggest green space might be a tool to advance health equity and provide ways forward for urban planners, parks managers, and public health professionals to address health disparities.
\end{abstract}

Keywords: atopic disease; birth outcomes; cardiovascular disease; diabetes; green infrastructure; mortality; normalized difference vegetation index (NDVI); obesity

\section{Introduction}

Disadvantaged groups around the world, including low-income and racially/ethnically minoritized people, experience a higher prevalence of certain diseases than more privileged groups, including more affluent and white people [1-3]. Scholars have defined such disproportionate disease rates as health disparities, inequalities, or inequities $[1,2,4,5]$ and have attributed them to poverty, subpar education, inadequate health care, and harmful environmental exposures for disadvantaged groups $[2,6]$. Health disparities are a particularly glaring issue in the United States (U.S.) [7], where, on average, individuals in the highest income bracket live six years longer than those in the lowest bracket [4], and black people live four fewer years than non-Hispanic white people [8]. Studies in many other countries with large shares of white populations (e.g., England, Australia, and South Africa) have found similar disparities based on race/ethnicity [9-11]. Due to these disparities, scholars and public health practitioners have advocated for efforts to achieve health equity $[1,2,12,13]$. Health equity describes the elimination of health disparities based on social or economic disadvantage and of their root causes, such as poverty and racial discrimination [1,2]. 
A growing body of literature shows green space (e.g., trees and parks) can have positive impacts on human health [14,15]. For instance, exposure to green space in residential environments is associated with better general health [16], higher birth weight [17], and lower mortality [18]. The health-promoting effects of green space have been explained by its ability to reduce exposure to air pollution and other harmful environmental exposures (mitigation), encourage healthy behaviors such as physical activity and sleep (instoration), and provide relief for cognitive processes and stress (restoration) $[19,20]$.

Some evidence suggests green space has larger health benefits for some sociodemographic groups than for others [21-24]. Indeed, socioeconomic and racial/ethnic vulnerabilities are commonly discussed moderating factors in proposed frameworks for studying the health benefits of nature contact [25-28]. We are not aware of reviews that have attempted to specifically examine these topics despite repeated calls for these reported effect modifiers [20,27]. The research that most closely addresses these calls is a systematic review of papers published through 2017 by Kabisch [28]. In this review, the author qualitatively describes relevant empirical studies and concludes that socioeconomic and sociodemographic factors are relevant modifiers or confounders of the health benefits of green space exposure; no quantitative synthesis was conducted.

Other reviews have also qualitatively described whether effect modification by socioeconomic status (SES) or race/ethnicity exists within certain domains of health. In particular, at least four literature reviews found that green space might have different benefits for birth outcomes depending on socioeconomic status (SES) and geography, although consensus regarding the direction of these effects (e.g., favoring lower SES groups) has not crystallized [17,29-31]. Another review described how some studies found low-SES groups showed greater health benefits if they lived in a greener neighborhood, relative to other populations [19].

The possibility of certain populations benefiting most from green space could be linked to another inequity: disadvantaged populations having less access to urban green space than more privileged groups in both Global North and Global South cities [32-35]. This intersection between health and environmental inequity warrants investigation into who benefits most from green space.

\subsection{Research Questions and Hypotheses}

In this review, we begin to clarify whether green space shows stronger associations with physical health for disadvantaged populations than for privileged groups. Here, disadvantaged individuals include those with low SES or who identify as a racially/ethnically minoritized group (i.e., in most Global North contexts, as not White). We advance the work of previous reviews by systematically analyzing and quantifying whether SES and race/ethnicity modify the associations between green space and several health outcomes. We ask four research questions that shed light on whether, and under which conditions, green space has the potential to help reduce health disparities.

- $\quad$ RQ1. Does green space show more protective effects for disadvantaged populations than for privileged groups?

- RQ2. What type(s) of green space (e.g., trees or parks) shows more protective effects for disadvantaged populations than for privileged groups?

- RQ3. Does green space show more protective effects on specific diseases and illnesses for disadvantaged populations than for privileged groups?

- RQ4. In which continent(s) does green space show more protective effects for disadvantaged populations than for privileged groups?

The first is the main question of this study. The second could provide preliminary information about which greening interventions have stronger protective effects for disadvantaged groups, which might inform cross-sectoral collaborations between public health and urban planning professionals [36-38]. The third and fourth could shed further light about under which conditions green space shows stronger protective effects for disadvantaged people. Specifically, RQ4 could provide information about in which sociopolitical 
contexts green space might be used as a strategy to help reduce health disparities, since scholars have suggested the importance of considering such contexts when planning health equity initiatives [2,12].

We hypothesize that green space does indeed provide stronger protective effects for disadvantaged populations compared to privileged groups (H1). We also hypothesize that measures of green land cover (e.g., NDVI greenness and tree canopy) show stronger effects for disadvantaged groups than park access (H2). Given the empirical and theoretical evidence to-date, we assert there is not enough information to formulate hypotheses regarding RQ3 and RQ4.

Rationale for $\mathrm{H} 1$ is provided by research about suppressed baselines, neighborhood dependency, and a lack of other health-promoting spaces. Regarding suppressed baselines, disadvantaged populations experience worse health and are exposed to greater environmental pollution than other groups, on average $[4,39,40]$. Since disadvantaged populations have a lot to gain regarding improvements in health and reductions in pollutants, neighborhood characteristics that promote health could show particularly strong effects [41,42]. Regarding neighborhood dependency, low-SES populations are generally less mobile due to lower vehicle ownership and spend more time in their residential neighborhoods [43-45]. Regarding the lack of other health-promoting settings, disadvantaged populations might not have access to private recreation/exercise opportunities like gyms or a backyard [44,45]. Thus, nearby accessible green space might have more beneficial impacts for disadvantaged people than for more privileged people. Furthermore, we expect that $\mathrm{H} 1$ will be supported because a recent review on green space and health found some studies showing greater protective effects from green space for low-SES than for high-SES people [15].

Regarding H2, parks in low-SES and racially/ethnically minoritized neighborhoods tend to be of lower quality (e.g., fewer amenities and lower maintenance) and have higher crime rates than parks in more privileged communities [32,33,46,47]. Specifically, studies around the world found SES and racial/ethnic inequities in park quality related to the number and types of park amenities [32,33]. Additionally, much of the work finding evidence of inequities in park safety has focused on the U.S. (see [47]). When parks are of low quality or are unsafe, studies in the U.S. show that some people choose not to access them and/or engage in less physical activity in them [48,49]. Perhaps as a result of that, research has shown associations between low park quality and low health status in North American contexts [48,50]. When focusing on measures of green land cover, we are not aware of studies showing disparities in the quality of vegetation (e.g., shrubs or trees) between privileged and disadvantaged communities. Therefore, because there is evidence of disparities in park quality but not in the quality of green land cover, we expect parks to have weaker protective effects for disadvantaged groups than measures of green land cover.

To answer our four research questions, we systematically review the literature on the protective effects of green space for the physical health outcomes for which there is evidence of disparities around the world (e.g., [8,51]): atopic diseases, birth outcomes, cancer, cardiovascular health/disease, diabetes, general health, mortality, and obesity (see Section 2.2). We search for studies that report differences in the health benefits of green space for individuals or neighborhoods based on SES or race/ethnicity.

\subsection{Health Disparities, Health Inequities, and Health Equity}

\subsubsection{Defining Terms}

Before presenting the methods and results of our systematic review, we introduce the definitions of health disparities, health inequities, and health equity, and we review the major health disparities based on SES and race/ethnicity. In a recent report, Braveman and colleagues defined health disparities (or inequalities) as "plausibly avoidable, systematic health differences adversely affecting economically or socially disadvantaged groups" ([1], p. 11). Regardless of whether these differences are linked to structural injustices, they 
negatively impact the lives of people already affected by social or economic disadvantage, and therefore raise ethical concerns $[1,52,53]$.

Health disparities have been linked to several determinants, including disadvantaged populations having less wealth, worse educational opportunities, less access to health care, and more harmful environmental exposures in residential and work settings than privileged groups $[2,3,6,41]$. Specifically, decades of research have shown that low-SES people and racially/ethnically minoritized people are disproportionately exposed to hazardous environments, such as power plants, oil refineries, high-traffic roadways, and landfills [54-56]. Such exposures contribute to worse health by increasing air pollution, noise, and heat [54-56].

Health inequities involve the recognition that differences in health outcomes are the result of unjust policies and societal structures $[1,2,12,52]$. Specifically, Braveman and colleagues state: "A health inequity is a particular kind of health disparity [ ... ] that is not only of concern for being potentially unfair, but which is believed to reflect injustice" ([1], p. 12). The most complex aspect of differentiating a health disparity from a health inequity is identifying sufficient evidence about unjust or deliberately harmful causes of such disparity $[1,52]$. Since racially/ethnically minoritized people are disproportionately exposed to environmental hazards (e.g., air pollution) and suffer from health disparities linked to exposure to such hazards (e.g., lung disease), those health disparities can be considered as health inequities $[1,52]$. In the U.S. and other majority-white countries, the link between harmful exposures and health inequities has been attributed to systemic racism $[57,58]$. Despite this research, there is little scholarly agreement about how much and which type of evidence warrants calling a health disparity a health inequity [1]. As such, in this paper, we use the phrase health disparities.

Health equity describes the reduction and eventual elimination of health disparities affecting disadvantaged groups, and the removal of the social determinants of health disparities, such as racial discrimination, poverty, and the lack of high-quality education [1,41]. In other words, "Health equity is the ethical and human rights principle motivating efforts to eliminate health disparities; health disparities are the metric for assessing progress toward health equity" ([1], p. 12). Since research showed that inequalities in exposure to environmental hazards contribute to health disparities [55,56], some scholars argued that environmental exposures such as green space can help move the needle toward health equity by mitigating hazardous exposures and providing other health-protective effects $[38,59]$.

\subsubsection{Identifying Health Disparities}

To gather evidence on health disparities around the world, we retrieved sources on this topic from governmental organizations, nonprofits, and scholars. This effort was not intended as a systematic review on health disparities, but to provide guidance on which health outcomes to include in this review. We focused on disparities based on SES and race/ethnicity because-based on the sources we retrieved-low-SES people and racially/ethnically minoritized people were the sociodemographic groups most often impacted by disparities $[2,4,8,60]$. Additionally, low-SES people and racially/ethnically minoritized people have been most often the populations of interest in environmental justice studies on the provision of green space $[32,35]$. Thus, we did not focus on health disparities based on sexual orientation, gender identity, veteran status, and disability.

Table 1 below summarizes the main health disparities we identified through our search. We reported those disparities that represent differences between privileged and disadvantaged groups that are either supported by citations in any of the sources we identified or that are reported as statistically significant in these sources (see notes in Table 1). To finalize the table, two authors cross-checked their evaluations of these reports to determine what disparities exist based on SES and race/ethnicity. 
Table 1. Summary of health disparities based on socioeconomic status and race/ethnicity.

\begin{tabular}{|c|c|c|c|}
\hline & Low SES & Racially/Ethn & ally Minoritized Group \\
\hline Disparity category & Source & Source & Minoritized group affected \\
\hline Life expectancy & {$[3,4,10,53,60]$} & {$[4,8,10,60]$} & Black people (U.S.), Indigenous people (Australia) \\
\hline All-cause mortality & {$[11,51]$} & {$[2,11]$} & $\begin{array}{l}\text { Native American people (U.S.), Black and Indian people } \\
\text { (South Africa) }\end{array}$ \\
\hline Homicide-related deaths & [2] & [2] & Black and Latinx people (U.S.) \\
\hline Number of chronic conditions & {$[3,8,10]$} & {$[8,10,61]$} & $\begin{array}{l}\text { Black and two-race people (U.S.), Indigenous people } \\
\text { (Australia), immigrants (Germany, Spain, Sweden, } \\
\text { Switzerland) }\end{array}$ \\
\hline Cardiovascular health/disease & {$[2,4,8,10]$} & {$[2,4]$} & Black people (U.S.) \\
\hline Cancer & {$[2,10]$} & & \\
\hline Obesity or overweight & {$[2-4,8,10]$} & {$[4,8,61,62]$} & $\begin{array}{l}\text { Black and Latinx people (U.S.), non-White people (The } \\
\text { Netherlands), immigrants (Germany, Sweden) }\end{array}$ \\
\hline Diabetes & {$[2,4,8,10]$} & {$[4,8,62]$} & $\begin{array}{l}\text { Black, Asian, Latinx, and Native American people (U.S.), } \\
\text { non-White people (The Netherlands) }\end{array}$ \\
\hline $\begin{array}{l}\text { Atopic diseases (e.g., asthma, } \\
\text { eczema) }\end{array}$ & [8] & [8] & Black and Native American people (U.S.) \\
\hline Poor self-reported health & {$[4,7,8,51,53]$} & {$[4,8-10,61,63]$} & $\begin{array}{l}\text { Black, Native American, and Latinx people (U.S.), } \\
\text { Indigenous people (Australia), non-White people (United } \\
\text { Kingdom), immigrants (France, Germany, The Netherlands, } \\
\text { Sweden, Switzerland), ethnically minoritized people as } \\
\text { opposed to Han Chinese (China) }\end{array}$ \\
\hline Preterm births & [64] & {$[2,4,8]$} & Black people (U.S.) \\
\hline Infant mortality & [4] & {$[2,65]$} & Black people (U.S.), Black people (South Africa) \\
\hline
\end{tabular}

Notes: Disparities describe a condition in which a disadvantaged group (e.g., low-SES people) experience worse health outcomes than privileged people (e.g., wealthier people).

\section{Materials and Methods}

\subsection{Article Search}

We adopted the standards for systematic reviews described in the preferred reporting items for systematic reviews and meta-analyses (PRISMA) [66] (Figure 1). The PRISMA checklist for this paper is reported in Table S13. To retrieve relevant articles, we reviewed five databases: CINAHL, Cochrane, PubMed, Scopus, and Web of Science. Additionally, we selected keywords from previous systematic reviews on green space and health and access to green space (see Table S2). Inclusion criteria included:

1. Report at least one of the measures of physical health outcomes described in the introduction (atopic diseases, birth outcomes, cancer, cardiovascular health/disease, diabetes, general health, mortality, and obesity);

2. Report at least one measure of objective or perceived green space provision or exposure. Green space measures include access to parks, level of residential vegetation (e.g., greenness), access to a residential garden, and others [67];

3. Perform inferential statistical analyses (e.g., regressions) on primary data;

4. Find that either the entire study population or a subsample (e.g., high-SES people) shows a beneficial relationship between green space and health;

5. Analyze whether the size or direction of the association between green space and physical health differs between disadvantaged and privileged populations (e.g., splitsample analyses or interaction tests);

6. Be published in peer-reviewed journals and written in English.

We conducted all searches on 17 April 2019, and then screened the titles, then the abstracts, and finally the full texts of the papers we identified through the search. All four authors participated in the screening process. At least two authors screened each title, abstract, and full text for inclusion, and they resolved disagreements about whether a paper was to be included or excluded by discussing each paper in relation to the above inclusion criteria. This ensured that at least two researchers agreed on whether an article was to be 
included. Among the 860 papers identified for full-text screening, 405 articles reported positive associations between green space and health, whereas 95 articles reported null or negative associations (other articles did not study the green space-health association or were literature reviews). The screening process resulted in 90 articles meeting the inclusion criteria: 85 papers examined effect modification by SES and 25 by race/ethnicity ( 20 papers examined effect modification for both SES and race/ethnicity). For most steps described in the method section, additional details are provided in the Methodological Details (see Supplementary Materials).

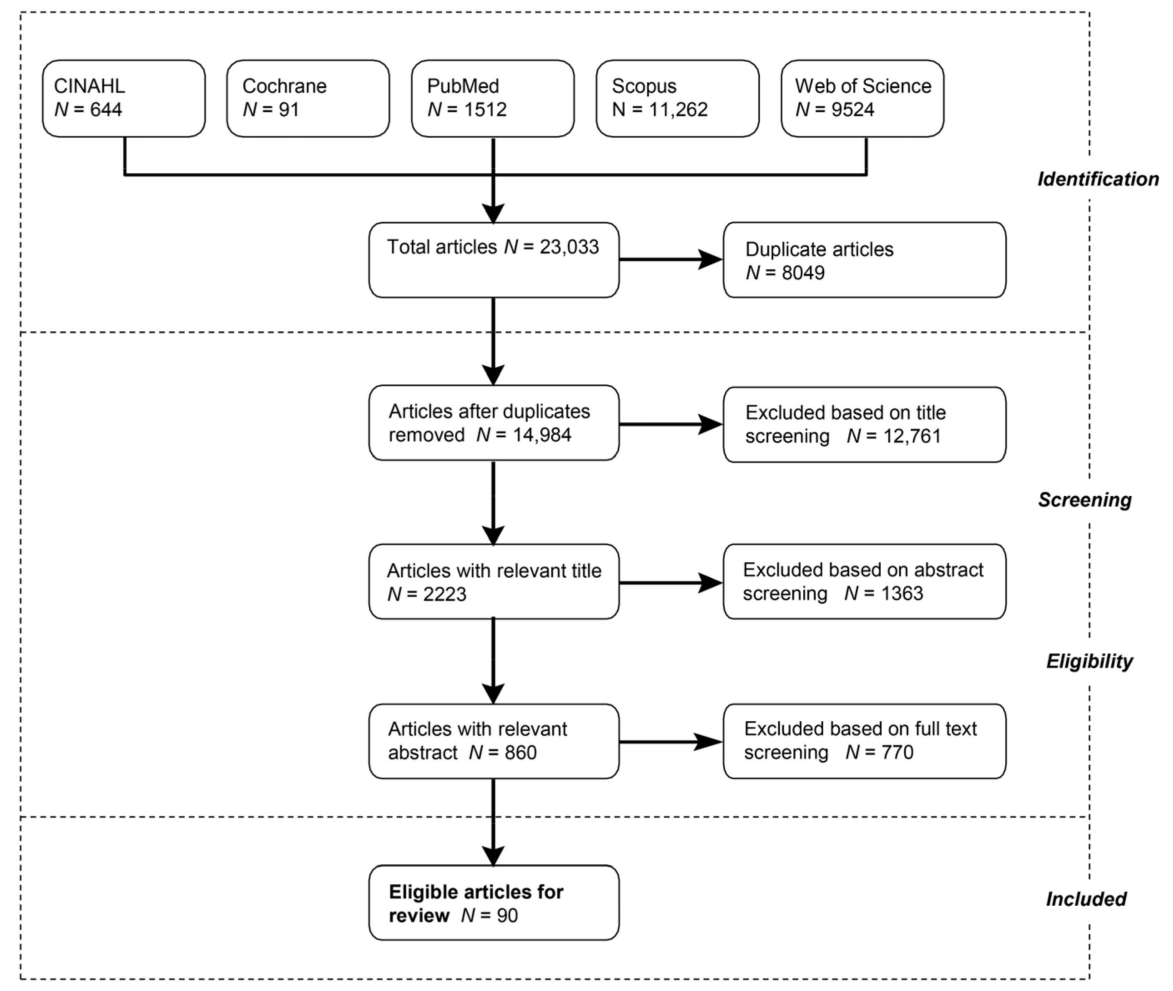

Figure 1. Search, screening, and selection process following the preferred reporting items for systematic reviews and meta-analyses (PRISMA) protocol.

\subsection{Data Extraction}

Next, we extracted data from the 90 included journal articles, including the study design, continent and country, sample, health outcome(s), green space type, results of the effect modification tests, and analysis of methodological bias and other ancillary attributes (see Table S4 for a complete list). As for the data screening process, all four authors participated in the data extraction. At least two authors worked independently to extract data from each included article, and they resolved disagreements in how they coded specific elements (e.g., green space type) by referring to the codebook presented in Table S4.

Similar to other recent systematic reviews on green space [68,69], we entered multiple rows in the spreadsheet for the same article if the article included more than one of the following characteristics: (1) research design (i.e., cross-sectional or longitudinal); (2) health outcome type; (3) green space type; (4) distance between the study's unit of analysis and green space; (5) green space measurement, including objective (e.g., GIS) or subjective evaluations; or (6) cities or countries where data were collected, if results were reported for separate samples. This process resulted in a greater number of rows than the number of articles alone since 28 articles were separated into multiple rows. Specifically, 122 rows of data reported effect modification by SES, and 30 rows of data reported effect modification by race/ethnicity.

We classified green space types into four categories based on previous literature $[67,70,71]$ : green land cover, public green space, gardens, and nature-based programs (see Table S4). 
Green land cover was a broad category that referenced what many scholars call "green space" and encompassed any setting with live vegetation [70]. Therefore, studies assigned to this category were those that used satellite-derived indices (e.g., normalized difference vegetation index (NDVI)) or land use and land cover-derived (LULC) datasets to measure the coverage of natural areas within a geographic area [71]. Since these datasets were unable to distinguish where the green cover was located and for whom exposure was likely, green space measured within this category likely captured settings with specific purposes and allowed users (e.g., parks, greenways, and gardens) [20,72]. Other studies examined those settings with specific purposes and users exclusively, and we categorized these studies into the next two categories: public green space (e.g., parks) or private green space (e.g., gardens). Finally, in acknowledgment of the growing body of literature that examines the health benefits of green exercise and the potential for effect modification by SES or race/ethnicity in these studies [73], we considered investigations that assessed nature-based programs as a distinct category because such programs paired green space exposure (e.g., in a park) with specific activities (e.g., exercise) [69].

Our main measures of interest were the results of effect modification tests by SES and race/ethnicity. After examining recent systematic reviews, we did not find any robust methodological precedents to code the direction of effect modifications beyond counts of studies and directionality of findings (i.e., number of articles showing increased CVD risk with greater racial/ethnic segregation) [74]. Therefore, we created a novel method that accounts for the presence of multiple analyses within a single article [68] and, corresponding, a spectrum of possible findings in a given article: from harmful in all analyses to harmful in some analyses/null in all analyses/protective in some/protective in all analyses. The development of this method was based on in-depth discussions among the authors. We coded the effect modification as 1.0 if green space showed more protective effects for a disadvantaged group (e.g., low-SES or racially/ethnically minoritized people) than a privileged group; as 0.0 if there were no differences between disadvantaged and privileged groups; and as -1.0 if green space had more protective effects for privileged groups (e.g., high-SES or white people) than disadvantaged groups. As all studies analyzing effect modification by race/ethnicity focused on countries with a white population of European descent that holds political and economic power, we considered all other groups as racially/ethnically minoritized (e.g., Latinx people in the U.S., indigenous people in Australia).

The studies we included either reported effect modification as split-sample analyses (e.g., showing the green space-health association for separate groups of low-SES vs. highSES people) or as interaction tests (e.g., multiplicative interaction terms between green space and SES measures). For interaction tests, we coded that there was a difference in the effect of green space between disadvantaged and privileged groups (e.g., value of 1.0 or -1.0$)$ if the interaction term was significant $(p<0.05)$; otherwise, we coded the effect modification as 0.0 . For split-sample analyses, we coded the effect modification as 1.0 or -1.0 in either of the following cases: one sample showed significant protective effects and the other did not; both samples showed significant protective effects, but one sample's effects were more protective and their $95 \%$ confidence intervals did not overlap those of the other sample. Otherwise, we coded the effect modification as 0.0. When split-sample analyses included more than two groups (e.g., income quartiles), we examined whether there were differences in protective effects below/above the median or the mean (whichever was reported): for example, we coded the effect modification as 1.0 if quartile 2 of income showed more protective effects than quartile 3 of income.

Some articles reported both split-sample and interaction tests of effect modification for the same row of data (e.g., associations between public green space and diabetes). In these cases, we averaged the values of the effect modification codes that applied to each effect modification analysis. We also averaged effect modification (EM) values when articles reported several effect modification tests for the same health outcome type (e.g., both body mass index and waist circumference for obesity-related measures) or multiple effect modification tests for the same green space type (e.g., both park proximity and park 
acreage for public green space). In these circumstances, we averaged EM values because we did not have definitive information to weigh one condition more than another (e.g., park proximity and park acreage). As a result of averaging, effect modification values can assume any decimal value between -1.00 and 1.00 (e.g., -0.50 and 0.33 ). The process of assigning values for the effect modification in each row resulted in a good inter-rater agreement between two researchers extracting data for EM SES (82\%) and an acceptable agreement for EM race/ethnicity (65\%). The latter was due to inconsistent understandings among the research team about what constituted a racially/ethnically minoritized group in countries around the world during the first round of coding. We addressed this issue by reviewing definitions of what constitutes a minoritized group in the countries where the sample studies were set in subsequent rounds of coding, which were then used to compile the final dataset.

\subsection{Methodological Bias and Quality of Evidence}

We also evaluated the potential for methodological bias. Building on Radke et al.'s (2019) work [75], we developed a bias evaluation instrument including four categories that are relevant for the green space-health connection: (1) study design, (2) green space exposure, (3) use and justification of confounders, and (4) statistical analysis (see Table S4 and 2.1.5 in the Supplementary Materials for more details). Using these four categories, we assigned quality scores to each row of data representing an inferential statistical analysis, summed up the scores for each category (see Table S4), and calculated the percentage of total possible quality points for each row. Then, we averaged these percentages in articles with multiple rows of data. As for the rest of the data extraction process, at least two authors vetted each article's scores for methodological bias. After this process, we classified studies based on five levels of quality: excellent ( $\geq 81 \%$ of the total possible quality points), good $(60-80 \%)$, fair $(40-60 \%)$, poor $(20-40 \%)$, and very poor $(<20 \%)$.

We also judged the quality of evidence by calculating the average quality score across the samples of papers evaluating EM by SES and EM by race/ethnicity. Following Radke et al.'s (2020) review on phthalate exposure [76], we judged the quality of evidence based on (1) the number of articles included in our review, (2) the quality of such studies, as determined by our methodological bias calculations, and (3) the pooled confidence of effects/effect size, as determined by our innovative way of combining EM results. Two authors worked on evaluating the quality of evidence of the included articles.

For each effect modification analysis (SES and race/ethnicity), we assigned a score of robust evidence for, moderate evidence for, slight evidence for, indeterminate evidence for, or compelling evidence against effect modification. Specifically, robust and moderate strength of evidence described evidence that clearly supported the effect modification in favor of one group more than another; these two categories were differentiated by the quantity and quality of relevant studies. Slight and indeterminate described evidence for which uncertainties prevented drawing a conclusion regarding effect modification, due to limited quantity, quality, or pooled effects; ultimately, these categories strongly indicate a need for additional research. Last, compelling evidence of no effect required several high-quality studies with consistently null results for effect modification tests.

\subsection{Data Analysis}

We analyzed articles reporting effect modification (EM) by SES (122 rows, 85 articles) and articles reporting EM by race/ethnicity (30 rows, 24 articles) separately using $\mathrm{R}$ (Version 4.02; R Core Team, Vienna, Austria) [77]. Statistical significance was indicated by $p<0.05$. For RQ1, we computed descriptive statistics (means and standard deviations) for the EM values for SES and race/ethnicity, examining whether green space has more protective effects for low-SES versus high-SES people and for white versus racially/ethnically minoritized people. For RQ2-RQ4, we ran Kruskal-Wallis tests (stats package v3.6.2) followed by Dunn's post-hoc pairwise comparisons (FSA package v0.8.30) to determine whether there were statistically significant differences in EM values based on the green 
space type (RQ2), health outcome type (RQ3), and continent (RQ4). We ran Kruskal-Wallis tests, rather than one-way ANOVA tests, because the EM values for SES and race/ethnicity were not normally distributed. Kruskal-Wallis tests are non-parametric analyses that compare mean ranks between three or more independent groups [78]. We ran post-hoc Dunn's tests to examine whether there were statistically significant differences in the mean ranks of EM values between each pair of groups (e.g., North America vs. Europe for RQ4). We conducted Dunn's tests regardless of whether Kruskal-Wallis tests were significant because we were interested in examining comparisons between specific groups $[79,80]$. To evaluate the extent to which bias was disproportionately present across our sample, and in particular, within those categories of interest for RQ2, RQ3, and RQ4, we compared quality scores between categories of rows for green space type, health outcome type, and continent. We then reported only those quality scores for pairwise comparisons that were significant and remained significant in all sensitivity analyses for parsimony (see below).

We conducted two sets of sensitivity analyses. In the first, we recoded the continuous EM values for SES and race/ethnicity into integers $(-1,0$, and 1$)$. We assigned -1 if the EM value was negative $(-1 \leq \mathrm{EM}$ value $<0)$ and 1 if the EM value was positive $(0>\mathrm{EM}$ value $\geq 1$ ). As a sensitivity analysis for RQ1, we computed descriptive statistics (means and standard deviations) for the recoded EM values for SES and race/ethnicity. For RQ2-RQ4, we built contingency tables and used Fisher's exact tests (stats package v3.6.2), because some cell counts had fewer than five observations [81], and post-hoc pairwise comparisons (rcompanion package v2.3.25), to determine whether, for example, the EM values were statistically significantly different based on the continent (RQ4).

In the second sensitivity analysis, we removed the three rows that measured green space as nature-based programs, from the dataset. Through this analysis, we aimed to only focus on measures representing accessible green space and exclude measures representing structured activities in green space such as exercise. Using this dataset, we conducted the same tests described for the main analysis (i.e., descriptive statistics, Kruskal-Wallis tests, and Dunn's tests).

\subsection{Articles Finding Null or Negative Associations between Green Space and Health}

We also examined the subsample of articles in which (a) the green space-health relationship was null or negative and (b) effect modification by SES and/or race/ethnicity was studied. We conducted this separate search and analysis as a robustness check to our main analysis (RQ1). One could imagine a situation where these studies showed that low-SES and/or racially/ethnically minoritized people experienced more harmful impacts than privileged groups. Such a hypothetical situation would counterbalance the expected findings of our main analysis, regarding low-SES and/or racially/ethnically minoritized people experiencing more beneficial impacts than privileged groups.

For this analysis, we rescreened the full texts of the 860 articles with relevant abstracts to identify articles with null or negative findings for effect modification. Through this process, we retrieved seven relevant articles, all of which found null associations between green space and health. Five of these examined effect modification by SES, and two of these studied effect modification by race/ethnicity. We analyzed the sign of the effect modification tests following the same process described for the main sample to examine whether harmful effects were stronger amongst SES or racial/ethnic groups.

\section{Results}

\subsection{Descriptive Statistics}

Table 2 lists the articles included in this review, and key characteristics related to this study. As noted earlier, more articles reported effect modification (EM) by SES $(n=85,94 \%)$ than EM by race/ethnicity $(n=25,28 \%)$. Figure 2 displays the descriptive statistics for key characteristics of the 90 included studies. The green space type that was studied most frequently was green land cover followed by public green spaces. The most commonly studied health outcome types were obesity-related measures and cardiovascular 
health/disease. We found studies focusing on people living in every continent except for Africa, and most articles analyzed settings in North America (principally, the U.S.) and Europe; therefore, the results may best speak to the potential for effect modification within these two regions, and continental comparisons may speak only to differences in effects between U.S. and European populations. The sample size of these studies ranged between 106 (individual-level study) and 97,574,613 (ecological study). None of the included studies were experimental, most were cross-sectional $(n=79,88 \%)$, and few were longitudinal ( $n=11,12 \%)$. The articles were published between 2003 and 2019, and most $(n=83,92 \%)$ in the 2012-2019 period (see Figure S1).
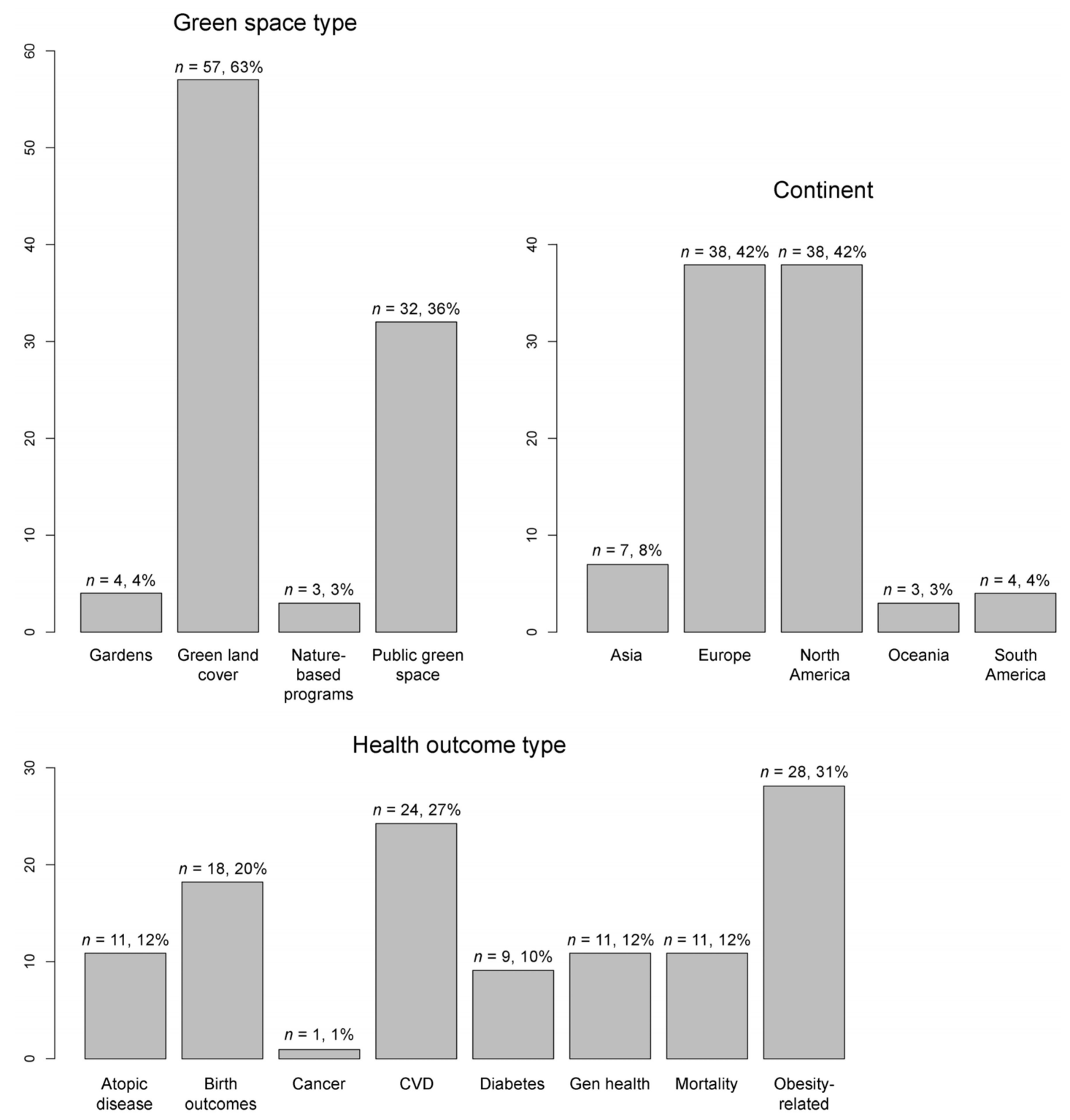

Figure 2. Descriptive statistics for the 90 included papers. $C V D=$ cardiovascular health $/$ disease. Gen health $=$ general health.

In addition to the green space categories, other measures of green space exposure also varied quite considerably in our sample. Among all analyses focusing on EM by SES and/or race/ethnicity, 90 percent operationalized green space through objective measures (e.g., remote sensing), whereas the remaining 10 percent relied on subjective measures (e.g., surveys). Regarding the units of analyses, 85 percent focused on individuals, 9 percent on neighborhoods (e.g., census tracts in the U.S. and Lower Layer Super Output Areas in 
England/Wales), and 6 percent on cities or counties. Among the analyses using geographic information systems to measure green space exposures, 73 percent used a distance-based approach (e.g., radial buffers around homes, distances to parks) and the remaining 27 percent a container approach (see $[71,82,83])$. Additionally, of the analyses using remotely sensed raster datasets (e.g., Landsat/MODIS-derived NDVI), 70 percent used resolutions between 2 and $30 \mathrm{~m}^{2}, 23$ percent used resolutions larger than $250 \mathrm{~m}^{2}$, and 7 percent used resolutions of $1 \mathrm{~m}^{2}$ or smaller (no papers used resolutions between 31 and $250 \mathrm{~m}^{2}$ ).

Table 2. Articles included in the review

\begin{tabular}{|c|c|c|c|c|}
\hline Authors and Date & EM Focus & Green Space Type (s) & Health Outcome Type (s) & Continent \\
\hline Abelt and McLafferty (2017) [84] & SES & Green land cover & Birth outcomes & North America \\
\hline Agay-Shay et al. (2014) [85] & SES & Green land cover & Birth outcomes & Europe \\
\hline Agay-Shay et al. (2019) [86] & SES & Green land cover & Birth outcomes & Europe \\
\hline Agyemang et al. (2017) [87] & Race & Public green space & CVD & Europe \\
\hline Alexander et al. (2013) [88] & Race & Public green space & Obesity-related & North America \\
\hline Astell-Burt et al. (2014) [89] & SES & Public green space & Diabetes & Oceania \\
\hline Björk et al. (2008) [90] & SES & Green land cover & $\begin{array}{l}\text { General health, } \\
\text { Obesity-related }\end{array}$ & Europe \\
\hline Brindley et al. (2018) [91] & SES & Gardens & General health & Europe \\
\hline Brown et al. (2016) [92] & SES & Green land cover & $\begin{array}{l}\text { CVD, Diabetes, } \\
\text { General health }\end{array}$ & North America \\
\hline Browning and Rigolon (2018) [93] & SES, Race & Green land cover & Obesity-related & North America \\
\hline Casey et al. (2016) [94] & SES & Green land cover & Birth outcomes & North America \\
\hline Coppel and Wüstemann (2017) [95] & SES & Public green space & General health & Europe \\
\hline Crouse et al. (2017) [96] & SES & Green land cover & Mortality & North America \\
\hline Cummins and Fagg (2012) [97] & SES & Public green space & CVD & Europe \\
\hline Cusack et al. (2017a) [98] & SES, Race & Green land cover & Birth outcomes & North America \\
\hline Cusack et al. (2017b) [99] & SES, Race & Green land cover & Birth outcomes & North America \\
\hline Cusack et al. (2018) [100] & SES, Race & Green land cover & Birth outcomes & North America \\
\hline da Silveira and Junger (2018) [101] & SES & Green land cover & CVD & South America \\
\hline Dadvand et al. (2012a) [102] & SES & $\begin{array}{l}\text { Green land cover, } \\
\text { Public green space }\end{array}$ & Birth outcomes & Europe \\
\hline Dadvand et al. (2012b) [103] & SES & Green land cover & Birth outcomes & Europe \\
\hline Dadvand et al. (2014a) [104] & SES & $\begin{array}{l}\text { Green land cover, } \\
\text { Public green space }\end{array}$ & $\begin{array}{l}\text { Atopic disease, } \\
\text { Obesity-related }\end{array}$ & Europe \\
\hline Dadvand et al. (2014b) [105] & SES, Race & Green land cover & Birth outcomes & Europe \\
\hline Dadvand et al. (2018) [106] & SES & Public green space & Diabetes & Asia \\
\hline D'Agostino et al. (2018a) [107] & SES & Nature-based programs & CVD, Obesity-related & North America \\
\hline D'Agostino et al. (2018b) [108] & SES & Nature-based programs & CVD, Obesity-related & North America \\
\hline Dalton et al. (2016) [109] & SES & Green land cover & Diabetes & Europe \\
\hline de Keijzer et al. (2017) [110] & SES & Green land cover & Mortality & Europe \\
\hline de Vries et al. (2003) [111] & SES & $\begin{array}{l}\text { Green land cover, } \\
\text { Gardens }\end{array}$ & General health & Europe \\
\hline Demoury et al. (2017) [112] & SES & Green land cover & Cancer & North America \\
\hline Donovan et al. (2013) [113] & SES & Green land cover & Atopic disease, CVD & North America \\
\hline Donovan et al. (2018) [114] & SES, Race & Green land cover & Atopic disease & Oceania \\
\hline Dzhambov et al. (2018) [115] & SES & Green land cover & CVD & Europe \\
\hline Ebisu et al. (2016) [116] & SES, Race & Green land cover & Birth outcomes & North America \\
\hline Egorov et al. (2017) [117] & SES, Race & Green land cover & CVD & North America \\
\hline Eldeirawi et al. (2019) [118] & SES & Green land cover & Atopic disease & North America \\
\hline Fan and Jin (2014) [119] & SES, Race & Public green space & Obesity-related & North America \\
\hline Fong et al. (2018) [120] & SES, Race & Green land cover & Birth outcomes & North America \\
\hline Foster and Weinstein (2019) [121] & SES & Public green space & Obesity-related & North America \\
\hline Gidlow et al. (2016) [122] & SES & Green land cover & Mortality & Europe \\
\hline Glazer et al. (2018) [123] & SES, Race & Green land cover & Birth outcomes & North America \\
\hline Groenewegen et al. (2018) [124] & SES & Green land cover & $\begin{array}{l}\text { Atopic disease, CVD, } \\
\text { Diabetes, General health }\end{array}$ & Europe \\
\hline Hobbs et al. (2017) [125] & SES & Public green space & Obesity-related & Europe \\
\hline
\end{tabular}


Table 2. Cont

\begin{tabular}{|c|c|c|c|c|}
\hline Authors and Date & EM Focus & Green Space Type (s) & Health Outcome Type (s) & Continent \\
\hline Hobbs et al. (2018) [126] & SES & Public green space & Obesity-related & Europe \\
\hline Hughey et al. (2017) [127] & SES, Race & Public green space & Obesity-related & North America \\
\hline Hystad et al. (2014) [128] & SES, Race & Green land cover & Birth outcomes & North America \\
\hline James et al. (2016) [129] & SES, Race & Green land cover & Mortality & North America \\
\hline Ji et al. (2019) [130] & SES & Green land cover & Mortality & Asia \\
\hline Jilcott Pitts et al. (2013) [131] & SES & Public green space & Obesity-related & North America \\
\hline Kihal-Talantikite et al. (2013) [132] & SES & Public green space & Birth outcomes & Europe \\
\hline Kling et al. (2018) [133] & Race & Nature-based program & CVD, Obesity-related & North America \\
\hline Lachowycz and Jones (2014) [134] & SES & Public green space & CVD & Europe \\
\hline Lovasi et al. (2012) [135] & SES & Green land cover & Obesity-related & North America \\
\hline Maas et al. (2006) [136] & SES & Green land cover & General health & Europe \\
\hline Maas et al. (2006) [137] & SES & Public green space & $\begin{array}{l}\text { Atopic disease, CVD, } \\
\text { Diabetes, General health, }\end{array}$ & Europe \\
\hline Markevych et al. (2014) [138] & SES & Green land cover & Birth outcomes & Europe \\
\hline Mena et al. (2015) [139] & SES & Public green space & Obesity-related & South America \\
\hline Mitchell and Popham (2018) [140] & SES & Public green space & CVD, Mortality & Europe \\
\hline Mueller et al. (2018) [141] & SES, Race & Public green space & Mortality & Europe \\
\hline Nichani et al. (2017) [142] & SES, Race & Green land cover & Birth outcomes & Oceania \\
\hline Nieuwenhuijsen et al. (2018) [143] & SES & Green land cover & Mortality & Europe \\
\hline Orioli et al. (2019) [144] & SES & Green land cover & $\begin{array}{l}\text { Atopic disease, CVD, } \\
\text { Mortality }\end{array}$ & Europe \\
\hline Persson et al. (2018) [145] & SES & Green land cover & Obesity-related & Europe \\
\hline Petraviciene et al. (2018) [146] & SES & Green land cover & Obesity-related & Europe \\
\hline Pun et al. (2018) [147] & SES, Race & Green land cover & CVD & North America \\
\hline Reid et al. (2017) [148] & SES & Green land cover & General health & North America \\
\hline Richardson et al. (2018) [149] & SES & Green land cover & Birth outcomes & Europe \\
\hline Rossi et al. (2018) [150] & SES & Public green space & Obesity-related & South America \\
\hline Rossi et al. (2019) [151] & SES & Public green space & Obesity-related & South America \\
\hline Ruijsbroek et al. (2017) [42] & SES & Public green space & General health & Europe \\
\hline Sarkar (2017) [152] & SES & Green land cover & Obesity-related & Europe \\
\hline Schalkwijk et al. (2018) [153] & SES & $\begin{array}{l}\text { Gardens, Public green } \\
\text { space }\end{array}$ & Obesity-related & Europe \\
\hline Schuler and O'Reilly (2017) [154] & SES & Public green space & Obesity-related & North America \\
\hline Seo et al. (2019) [155] & SES & Public green space & CVD & Asia \\
\hline Singh et al. (2010) [156] & SES, Race & Public green space & Obesity-related & North America \\
\hline Sullivan et al. (2014) [157] & Race & Public green space & Obesity-related & North America \\
\hline Thiering et al. (2016) [158] & SES & Green land cover & Diabetes & Europe \\
\hline Triguero-Mas et al. (2015) [159] & SES & $\begin{array}{l}\text { Green land cover, } \\
\text { Public green space }\end{array}$ & General health & Europe \\
\hline Van Der Zwaard et al. (2018) [160] & SES & Gardens & Obesity-related & Europe \\
\hline Vienneau et al. (2017) [161] & SES & Green land cover & $\begin{array}{l}\text { Atopic disease, CVD, } \\
\text { Mortality, }\end{array}$ & Europe \\
\hline Villeneuve et al. (2012) [162] & SES & Green land cover & Atopic disease, Mortality & North America \\
\hline Villeneuve et al. (2018) [163] & SES & Green land cover & Obesity-related & North America \\
\hline Wang and Lan (2019) [164] & SES & Public green space & $\begin{array}{l}\text { Atopic disease, } \\
\text { Obesity-related }\end{array}$ & Asia \\
\hline $\begin{array}{l}\text { Wen and Kowaleski-Jones (2012) } \\
\text { [165] }\end{array}$ & Race & Public green space & Obesity-related & North America \\
\hline Wilker et al. (2014) [166] & SES & Green land cover & CVD & North America \\
\hline Wu et al. (2018) [167] & & $\begin{array}{l}\text { Green land cover, } \\
\text { Public green space }\end{array}$ & CVD & North America \\
\hline Xu et al. (2017) [168] & SES & Green land cover & $\begin{array}{l}\text { Atopic disease, CVD, } \\
\text { Diabetes }\end{array}$ & Asia \\
\hline Yang et al. (2019a) [169] & SES & Green land cover & CVD & Asia \\
\hline Yang et al. (2019b) [170] & SES & Green land cover & Diabetes & Asia \\
\hline Yeager et al. (2018) [171] & SES, Race & Green land cover & CVD & North America \\
\hline Yitshak-Sade et al. (2019) [172] & SES, Race & Green land cover & CVD & North America \\
\hline
\end{tabular}




\subsection{Summary of Findings on Methodological Bias and Quality of Evidence}

The analysis of methodological bias highlighted that most studies were either of good quality $(n=50,56 \%)$ or fair quality $(n=39,43 \%)$, whereas only one study was of poor quality (see Table S5). Frequent possible bias included observational cross-sectional designs, the lack of control for spatial autocorrelation, and the absence of sensitivity analyses. Specifically, among the four categories, we included in our bias evaluation instrument, research design scored the lowest-as demonstrated by studies earning only $52 \%$ of the possible quality score in this category, on average-likely due to the overrepresentation of observational cross-sectional studies. The category describing exposure showed studies receiving the highest scores ( $78 \%$ of the possible quality score earned, on average), as explained by good temporal alignments between measurements of exposures and health outcomes. The two categories describing confounding and analyses faired in between the two above ( $66 \%$ and $61 \%$ of the possible quality score was earned, respectively). For example, most studies controlled adequately for potential confounders of the green space-health association (e.g., SES and age), but some did not justify the control variables included in the final models (see Table S5).

Collectively, the quality of evidence for differences in protective effects by SES was moderate, given the relatively modest strength of the effect (see EM mean value in Section 4.3 ) and that the 85 studies that tested for this relationship earned only $63 \%$ of the possible quality points. The quality of evidence for differences in protective effects by race/ethnicity was indeterminate. Relatively few studies $(n=25)$ tested for this relationship, and despite earning moderate scores for the bias evaluation ( $66 \%$ of the possible quality points), the findings displayed too many null results to classify the evidence as slight or moderate.

\subsection{More Protective Effects for Whom?}

Results showed that green space had more protective effects for low-SES groups than for high-SES groups, as the mean of the EM values for SES was $0.263(\mathrm{SD}=0.619)$. The positive sign highlights that, across the reviewed studies, green space had more often stronger protective effects for low-SES groups than for high-SES groups. Figure 3 shows the frequency of EM values for both SES and race/ethnicity. The quality scores of analyses finding stronger protective effects for low-SES people, no differences, or stronger protective effects for high-SES people were comparable $(62 \%, 63 \%$, and $64 \%$ of the total possible quality points, respectively; see Table S5). Results for race/ethnicity showed no notable differences between White and racially/ethnically minoritized people, as the mean of the EM values was 0.064 ( $S D=0.598$; see Figure 3 ). The two sensitivity analyses (EM recoded as $-1,0$, and 1 , and nature-based programs removed from the sample) confirmed the results of the main analysis (see Table S7 and Figure S2 for the first sensitivity analysis; and Table S9 for the second). Thus, we found partial support for H1 (for SES but not for race/ethnicity).

The analysis of the seven articles reporting null/negative findings showed no evidence of effect modification (see Table S12). These findings confirm the robustness of our main results regarding green space having more protective effects for low-SES people than for affluent people.

\subsection{Does Green Space Type Matter?}

A Kruskal-Wallis test to compare mean ranks of EM value for SES by green space type showed marginally significant results $\left(\chi^{2}(3)=7.492, p=0.057\right)$. Dunn's post-hoc pairwise tests showed that public green space was significantly more likely to have stronger protective effects for low-SES people than green land cover, $p=0.012$ (see Table S6). For context, the quality scores of analyses focusing on public green space and green land cover were relatively similar ( $60 \%$ and $64 \%$, respectively). A Kruskal-Wallis test did not highlight differences in EM values for race/ethnicity based on green space type $\left(\chi^{2}(2)=2.926, p=0.231\right)$. Thus, we found no support for $\mathrm{H} 2$, as our results for SES showed 
just the opposite: Public green spaces displayed stronger protective effects for low-SES people than green land cover.
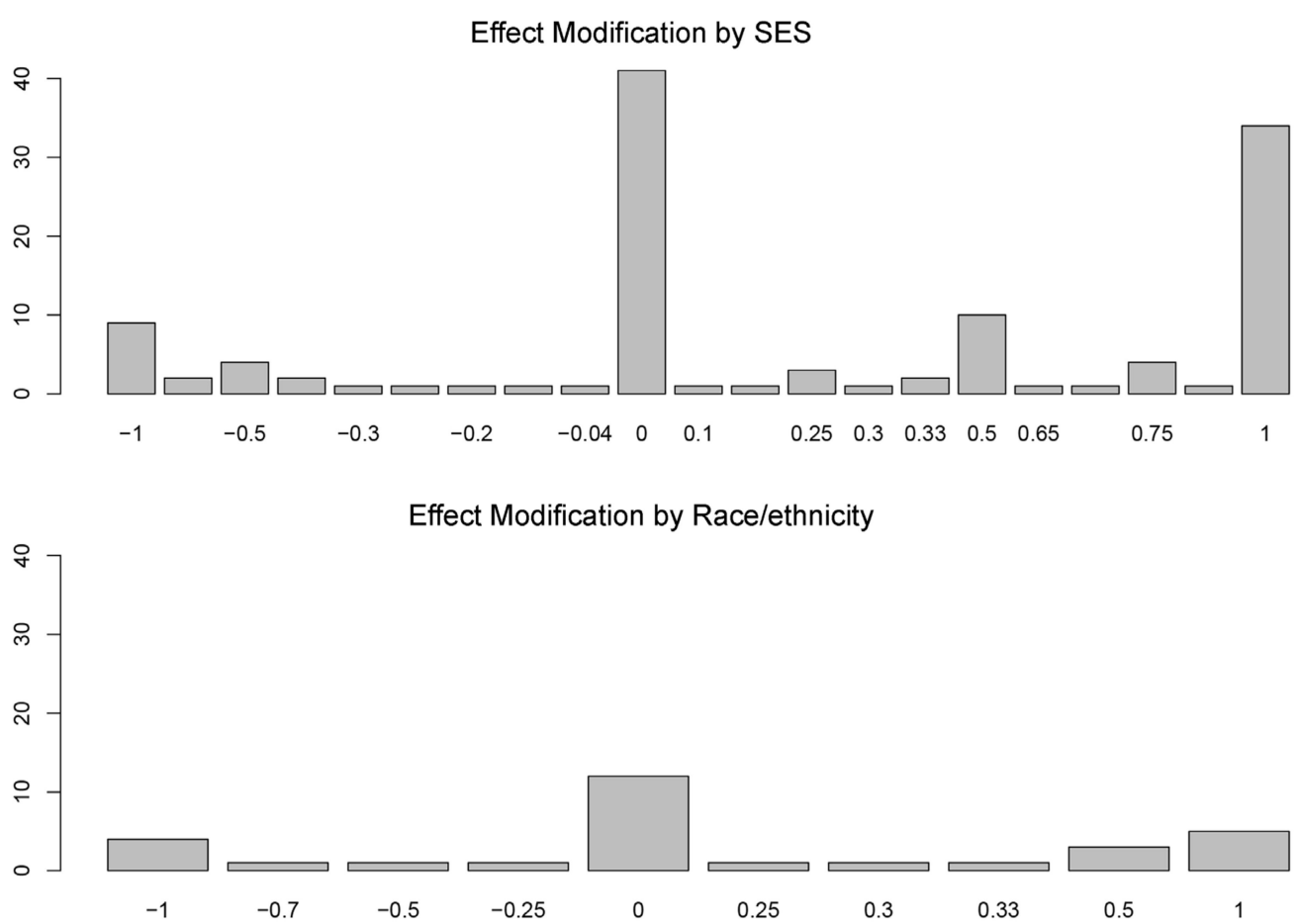

Figure 3. Bar charts showing the distributions of EM by SES and race/ethnicity. Scores of -1 indicate stronger protective effects for privileged populations (high-SES people or white people). Scores of 0 indicate no differences in protective effects between more and less disadvantaged populations. Scores of 1 indicate stronger protective effects for disadvantaged populations (low-SES people or racially/ethnically minoritized people). Comparisons between the two bar charts show that green space appears to exhibit stronger protective effects for low-SES people than for high-SES people, whereas green space does not show clear differences in protective effects by race/ethnicity.

We also tested whether EM values for SES and race/ethnicity varied by distance from green space, for a subsample of studies that used a fixed threshold to measure green space exposure (74 rows). The Kruskal-Wallis test for EM values for SES was significant $\left(\chi^{2}(3)=21.051, p<0.001\right)$, whereas the same test for the race/ethnicity EM values was not $\left(\chi^{2}(2)=4.250, p=0.119\right)$. Dunn's post-hoc pairwise tests for SES showed that green space distance ranges of 501-1000 m, 1001-2000 m, and larger than $2000 \mathrm{~m}$ had more protective effects for low-SES versus high-SES people than the 0-500 $\mathrm{m}$ range (all $p<0.05$, Table S6). The quality scores of analyses that considered different distance thresholds were similar for the $0-500 \mathrm{~m}$ and $501-1000 \mathrm{~m}$ ranges (64\% and 63\%, respectively), but lower for the two highest thresholds ( $59 \%$ for $1001-2000 \mathrm{~m}$, and $55 \%$ for $2000+\mathrm{m}$ ). The two sensitivity analyses generally confirmed the findings for green space type and distance (see Table S8 and Figure S3 for the first sensitivity analysis; and Tables S10 and S11 for the second).

Means for the EM values of different green space types and green space distances are reported in Table 3 for illustrative purposes. Although tests for the EM values by race/ethnicity were not significant, the descriptive statistics in Table 3 showed similar trends as those for SES: public green space had a larger mean than green land cover (i.e., public green space had more protective effects for racially/ethnically minoritized people than green land cover), and larger green space distances (e.g., 1001-2000 m) had higher means than the smallest (i.e., $0-500 \mathrm{~m}$ ).

\subsection{Does the Type of Health Outcome Matter?}

A Kruskal-Wallis test to compare mean ranks of EM value for SES by type of health outcomes was not significant $\left(\chi^{2}(7)=8.306, p=0.306\right)$. Yet Dunn's post-hoc pairwise tests 
showed that green space had stronger beneficial effects for low-SES people (as compared to high-SES people) for general health than birth outcomes, $p=0.010$, and for cardiovascular health/disease than for birth outcomes, $p=0.065$ (Table S6). The first sensitivity analyses (EM values recoded as $-1,0$, or 1 ) for SES showed diverging results from the main analysis, as neither of the significant pairwise comparisons in the main analysis remained so when recoding (see Table S8 and Figure S7). The second sensitivity analysis (naturebased programs removed) highlighted similar findings to those of the main analysis (see Tables S10 and S11).

Table 3. Means for EM values classified by green space type, green space distance, health outcome type, and continent.

\begin{tabular}{|c|c|c|c|c|}
\hline & \multicolumn{2}{|l|}{ EM SES } & \multicolumn{2}{|c|}{ EM Race/Ethnicity } \\
\hline & Mean (SD) & $n$ & Mean (SD) & $n$ \\
\hline \multicolumn{5}{|l|}{ Green space type } \\
\hline Gardens & $0.500(0.577)$ & 4 & & \\
\hline Green land cover & $0.154(0.594)$ & 78 & $-0.007(0.644)$ & 20 \\
\hline Nature-based program & $0.500(0.577)$ & 3 & $0.500(0.000)$ & 2 \\
\hline Public green space & $0.447(0.585)$ & 36 & $0.135(0.570)$ & 8 \\
\hline \multicolumn{5}{|l|}{ Green space distance } \\
\hline $0-500 \mathrm{~m}$ & $-0.009(0.529)$ & 52 & $-0.060(0.584)$ & 15 \\
\hline $501-1000 \mathrm{~m}$ & $0.518(0.464)$ & 14 & $1.000(0.000)$ & 1 \\
\hline $1001-2000 \mathrm{~m}$ & $0.750(0.500)$ & 4 & $1.000(0.000)$ & 2 \\
\hline$>2000 \mathrm{~m}$ & $1.000(0.000)$ & 4 & & \\
\hline \multicolumn{5}{|l|}{ Health outcome type } \\
\hline Atopic disease & $0.273(0.606)$ & 11 & $-0.250(0.000)$ & 1 \\
\hline Birth outcomes & $0.072(0.466)$ & 22 & $-0.036(0.506)$ & 11 \\
\hline Cancer & $0.000(0.000)$ & 2 & & \\
\hline Cardiovascular health/disease & $0.218(0.596)$ & 25 & $0.214(0.755)$ & 7 \\
\hline Diabetes & $0.425(0.472)$ & 10 & & \\
\hline General health & $0.559(0.519)$ & 17 & & \\
\hline Mortality & $0.091(0.943)$ & 11 & $0.500(0.707)$ & 2 \\
\hline Obesity-related & $0.305(0.613)$ & 24 & $0.009(0.653)$ & 9 \\
\hline \multicolumn{5}{|l|}{ Continent } \\
\hline Asia & $0.158(0.609)$ & 10 & & \\
\hline Europe & $0.448(0.564)$ & 61 & $0.625(0.478)$ & 4 \\
\hline North America & $0.022(0.559)$ & 44 & $-0.013(0.607)$ & 24 \\
\hline Oceania & $0.416(0.381)$ & 3 & $-0.125(0.176)$ & 2 \\
\hline South America & $0.250(0.957)$ & 4 & & \\
\hline
\end{tabular}

Note: SD represents standard deviation. $n$ represents the number of rows in which the effect modification was tested. The corresponding descriptive statistics for the first sensitivity analysis are in Figures S3-S10 and those for the second are in Table S9.

A Kruskal-Wallis test did not highlight differences in EM values for race/ethnicity based on the health outcome type $\left(\chi^{2}(4)=2.857, p=0.581\right)$. Yet the means shown in Table 3 suggest that green space might have stronger protective effects for racially/ethnically minoritized (as compared to white people) for cardiovascular health / disease (mean $=0.214$, $\mathrm{SD}=0.755, n=7)$.

\subsection{Does the Continent Matter?}

A Kruskal-Wallis test to compare mean ranks of EM value for SES by continent was significant $\left(\chi^{2}(4)=15.836, p=0.003\right)$. Dunn's post-hoc pairwise tests showed that green space had greater health benefits for low-SES people (as compared to high-SES people) in Europe than in North America, $p<0.001$ (Table S6). The two sets of sensitivity analyses confirmed this result (see Table S8 and Figure S9 for the first sensitivity analysis; and Tables S10 and S11 for the second). The quality scores of analyses focusing on Europe and North America were relatively similar (62\% and 65\%, respectively).

The Kruskal-Wallis test for race/ethnicity was not significant $\left(\chi^{2}(2)=4.467, p=0.107\right)$, but two Dunn's post-hoc pairwise comparisons were marginally significant: green space 
had stronger beneficial associations with health for racially/ethnically minoritized people in Europe as opposed to North America, $p=0.056$, and in Oceania as opposed to North America, $p=0.074$ (Table S6). The first sensitivity analysis for these tests (EM values recoded as $-1,0$, or 1 ) showed non-significant results (see Table S8), but the second (naturebased programs removed) highlighted consistent results to those of the main analysis (see Tables S10 and S11).

\section{Conclusions}

\subsection{Summary of Findings}

In this systematic review, we examined whether green space shows greater protective effects for the physical health of disadvantaged or privileged groups. By doing so, we aimed to gather evidence about whether green space can contribute to limiting health disparities and moving toward health equity. We analyzed 90 peer-reviewed articles that reported whether SES and/or race/ethnicity modified the association between green space and physical health outcomes. Fewer articles studied effect modification by race/ethnicity than by SES. Additionally, most studies that did focus on race/ethnicity were set in the U.S., where, due to systematic racism, race and ethnicity are important determinants of health outcomes [1]. The moderate quality of evidence scores for SES that emerged from our analysis of methodological bias makes us reasonably confident about these particular results, which are presented below. Yet the most significant methodological limitation affecting these studies was the frequent use of observational cross-sectional designs, which highlights the need for more research using longitudinal, experimental, or quasi-experimental designs. Several other recent reviews on green space and health highlighted a similar limitation among their included studies $[19,20,83,173]$. The indeterminate quality of evidence for race/ethnicity signals that these results should be interpreted with caution and emphasizes the need for future attempts to synthesize and add to the available evidence.

We found promising evidence for efforts to achieve health equity. As expected (H1), green space had greater protective effects for low-SES people and neighborhoods than for more affluent groups (Research Question 1). These findings are reinforced by two recent studies with similar conclusions that showed green space provides more health benefits in countries with lower income than in more affluent countries, likely because the latter have better medical service and more services to improve health than less wealthy countries $[174,175]$. We did not find noticeable differences in the protective effects of green space between white and racially/ethnically minoritized people, yet the relatively small sample of articles reporting effect modification by race/ethnicity $(n=24)$ warrants more research on this topic.

Our results also showed that public green space (e.g., parks) had stronger protective effects for low-SES groups (as opposed to high-SES groups) than measures of green land cover (e.g., greenness; Research Question 2). This is the opposite of what we expected (H2), since the poor quality of parks in disadvantaged areas, at least in the U.S. and Global South countries [32,33], should limit the protective effects of parks for disadvantaged groups. To our knowledge, fewer studies have found inequities in park quality in other contexts, such as Europe (e.g., $[176,177])$. Our unexpected findings may be explained by most parks being free and accessible to the public; they might be the only place for exercise for low-SES people who cannot easily afford private recreation options such as gyms [44,45]. Further, parks might serve as spaces for socialization and social well-being [178], which in turn might influence physical health [179]. Latinx and Black people in the U.S.-who are more likely to have lower SES than white people-use parks in groups for social activities more than white people $[180,181]$. Parks have also been identified by minoritized populations outside of the U.S. as determinants of health more so than other types of urban green spaces such as green streets [182].

Additionally, we found that when larger distances around one's home were considered, green space showed stronger protective effects for low-SES people than for more affluent groups. This might be in part because the benefits of green space are more 
consistently detected when measuring green spaces in a broad buffer from one's home (e.g., up to $2000 \mathrm{~m}$ ) than in a very small buffer (e.g., less than $400 \mathrm{~m}$ ) [183]. Broader neighborhood contexts may better estimate the activity spaces in which some forms of exposure that result in health outcomes, like physical activity and socialization, than narrower contexts [71]. Further, low-SES people and racially/ethnically minoritized people might walk longer distances and times than privileged groups, in part due to limited access to private vehicles [184], and therefore show beneficial associations with green space at greater distances than other populations. Thus, researchers might need to consider the broad neighborhood context when measuring green space exposure for low-SES people to accurately capture the protective effects of exposure.

Tests to examine whether the type of health outcome matters in whether disadvantaged groups benefit more from green space showed inconsistent results (Research Question 3). Although pairwise tests highlighted that that green space has stronger protective effects for low-SES people (as compared to high-SES people) for general health and cardiovascular health/disease than for birth outcomes, the first sensitivity analysis (EM values recoded as $-1,0$, and 1) did not show the same differences. It should also be noted that because we included eight types of health outcomes, many comparisons were between pairs with few cases, which limited statistical power.

Finally, we found strong differences by continent. Green space had stronger protective effects for low-SES people than high-SES people in studies focusing on Europe as opposed to North America (mostly representing studies in the U.S.). These findings might be because green space has higher quality in Europe's low-SES neighborhoods than in North America's disadvantaged neighborhoods. Indeed, among the studies in Rigolon's review [32], more than a dozen found inequities in park quality in the U.S., whereas only two found such inequities in European contexts (e.g., [176,177]). Additionally, Schüle et al.'s [34] recent review of studies in Europe does not shed light on whether inequities in green space quality exist in that continent. Further, most European countries have a welfare state form of government, which provides more public services for disadvantaged populations (e.g., universal health care) than the U.S. government [185]. Additionally, low-SES people of color in the U.S. face systemic racism and police violence; with evidence of police harassment and discrimination of low-SES people of color in parks [186,187], those individuals might choose to avoid parks. Europe's public health care systems might also push countries to invest in upstream health interventions such as parks, especially in low-SES areas where people with poor health status reside $[188,189]$.

Similar findings emerged for effect modification by race/ethnicity regarding green space type (Research Question 2) and continent (Research Question 4), although they were not statistically significant likely due to the small sample size. Green space had stronger protective effects for racially/ethnically minoritized people than white people when analyses focused on public green space (as opposed to green land cover) and focused on Europe (as opposed to North America).

\subsection{Strengths, Limitations, and Future Research}

The main strength of this review is its focus on SES and race/ethnicity as modifiers of the green space-human health relationship. To the best of our knowledge, this is the first systematic review that analyzed quantitatively whether green space can help advance health equity goals. Another strength of the review is its inclusion of eight types of physical health outcomes for which health disparities exist. Since we did not include mental health outcomes, future reviews could examine whether disadvantaged or privileged groups show stronger associations between green space and greater mental health [190]. An additional strength of this review is its global focus, as we included studies from five continents and uncover significant differences between findings in Europe and North America. Thus, when also considering our large sample of studies with effect modification by SES $(n=85)$, our findings might apply to low-SES people in a variety of contexts. 
Regarding limitations, we decided to create categories of health outcomes and green space to make inferential statistics possible rather than using the exact measures of health and exposure described in each article (for example, we classified tree canopy cover as green land cover). This choice might have resulted in a loss of detail regarding measures of green space and health. Yet, had we entered each individual measure for each green space and each health outcome, we would have had too many categories to draw meaningful conclusions about green space types and health outcome types. We also studied broad disease categories with diverse markers of disease. For example, the effect of green space on atopic diseases may differ across its broad measurements (i.e., allergies, asthma, and respiratory infection/disease/function/mortality) [191-194]. Our sample of papers within this disease category was too small to examine specific health endpoints. Our aggregated findings should be considered preliminary evidence rather than conclusive findings for these myriad aspects of respiratory health.

Relatedly, we were unable to pool estimates from individual papers and conduct formal meta-analyses due to the variability in reporting — and commonly the underreportingthe details of effect modification tests. Instead, our findings were calculated from our best attempt to systematically code the myriad ways to report the findings from these tests. As indicated in our moderate inter-rater agreement scores, this process was characterized by difficulty interpreting the directionality and statistical significance of many papers' findings. Our results may have differed if we had weighted articles' contributions by sample sizes and variance, for instance, as would have been accomplished with a formal meta-analysis had that option been available to us. Similar to the above discussion, we categorized studies based on continents, which albeit having some common sociopolitical characteristics and similarities regarding associations between green space and human health [175], include a range of diverse countries. Thus, our findings regarding continents mostly speak about differences between the United States (over-represented in the North American sample) and European countries.

Further, most of the studies we identified through our search were cross-sectional, and therefore more research is needed to ascertain whether green space causes greater protective effects for low-SES people as opposed to high-SES people. Alternative explanations for our findings include residential self-selection bias, which describes the possibility of people seeking healthier lifestyles choosing to live in areas that facilitate those lifestyles, such as green and walkable neighborhoods [195-197], and structural forces, such as racist attitudes in the housing market, which limit where disadvantaged people can live [198]. Finally, our sample of studies focusing on effect modification by race/ethnicity is relatively small, which makes the generalizability of those specific findings limited. In particular, only one study among the 90 included focused on indigenous people [114].

Our analysis also highlights the need for additional research on whether measures of disadvantage modify the green space-health associations. First, more studies are needed to understand whether race or ethnicity act as effect modifiers in the relationship between green space and health. Specifically, more work is needed in Europe, which is becoming more racially and ethnically diverse due to in-migration and refugee resettlement [199]. Second, more research could be conducted in Global South countries, most of which experience significant wealth inequalities [200]. Third, more studies that evaluate the health impacts of similar green space initiatives (e.g., tree planting programs) in disadvantaged and privileged communities are needed. Fourth, more research should examine whether, in socially-mixed neighborhoods such as gentrifying communities, green space-health associations are stronger for low-SES or high-SES people [201].

\subsection{Policy Implications}

Despite the limitations of this review and of the included studies, our results may have implications for public policies and initiatives on public health and green space. First, our main results suggest that green space could be used as a tool to promote health equity. Although several public agencies and nongovernmental organizations (NGOs) 
around the world have created and activated green space in low-SES communities to improve health outcomes among those populations $[38,59,202]$, the results of this review provide them with further evidence to advocate for more funding supporting green space in such communities.

Second, our results suggest that organizations working to achieve health equity may choose to prioritize public green space (e.g., parks) in low-SES communities over other types of green space (e.g., street trees). In this regard, several environmental justice NGOs in cities around the world have partnered with public agencies to build, maintain, and activate parks in disadvantaged communities [203-205]. Collaborations between health care providers and parks organizations are also emerging, as shown by the growth of park prescription (or ParkRx) programs, some of which have focused on disadvantaged populations $[59,206]$. Our findings also suggest that planners should consider the provision of green space for low-SES residents beyond the immediate surroundings of their homes $(0-500 \mathrm{~m})$ and look instead at thresholds up to $2 \mathrm{~km}$.

Third, our finding that green space had stronger protective effects for low-SES people (and to some extent racially/ethnically minoritized people) in Europe than in North America shows that context matters. In other words, health equity organizations might consider broader societal contexts such as access to health care, the geography of cities, and systemic racism when planning green space initiatives to address health disparities $[2,12,13]$. Our finding that context matters also suggests that green space is only one piece of the puzzle to achieve health equity, one that needs to be integrated with initiatives to provide access to housing and health care to disadvantaged groups and to remove hazardous exposures in their neighborhoods [1,2,12]. Ultimately, we hope that our findings will stimulate more research and policy initiatives on how green space can be integrated with other interventions to move the needle toward health equity.

Supplementary Materials: The following are available online at https:/ / www.mdpi.com/1660-4 $601 / 18 / 5 / 2563 / s 1$, Table S1. Databases used in previous reviews on green space and health and on access to green space. Table S2. Search terms used in reviews on green space and health and on access to green space. Table S3. Search expressions used in this review. Table S4. Codes included in the data extraction sheet. Table S5. Points assigned to each bias category for the articles included in the review. Table S6. Dunn's post-hoc pairwise tests for the Effect Modification (EM) values. Table S7. First Sensitivity analysis: Summary of statistical tests conducted. EM values were recoded as integers $(-1,0$, or 1$)$. Table S8. First Sensitivity analysis: Post-hoc pairwise comparisons for Fisher's exact tests for the Effect Modification (EM) values. EM values were recoded as integers $(-1,0$, or 1$)$. Table S9. Second sensitivity analysis (exclude nature-based programs): Means for EM values classified by green space type, green space distance, health outcome type, and continent. Table S10. Second sensitivity analysis (exclude nature-based programs): Kruskal-Wallis tests for the Effect Modification (EM) values. Table S11. Second sensitivity analysis (exclude nature-based programs): Dunn's post-hoc pairwise tests for the Effect Modification (EM) values. Table S12. Articles in which (a) the green spacehealth relationship was null or negative and (b) reported effect modification tests for such relationship. Table S13. PRISMA Checklist. Figure S1. Year of publication of the 90 articles included in this review. Figure S2. First sensitivity analysis: Effect modification (EM) for SES and Race/ethnicity. EM was recoded as $-1,0$, or 1 . Figure S3. First sensitivity analysis: Effect modification (EM) for SES classified by green space type. EM was recoded as -1 (high-SES people benefit more), 0 (no differences), or 1 (low-SES people benefit more). Figure S4. First sensitivity analysis: Effect modification (EM) for race/ethnicity classified by green space type. EM was recoded as -1 (White people benefit more), 0 (no differences), or 1 (non-White people benefit more). Figure S5. First sensitivity analysis: Effect modification (EM) for SES classified by green space distance. EM was recoded as -1 (high-SES people benefit more), 0 (no differences), or 1 (low-SES people benefit more). Figure S6. First sensitivity analysis: Effect modification (EM) for race/ethnicity classified by green space distance. EM was recoded as -1 (White people benefit more), 0 (no differences), or 1 (non-White people benefit more). Figure S7. First sensitivity analysis: Effect modification (EM) for SES classified by health outcome type. EM was recoded as -1 (high-SES people benefit more), 0 (no differences), or 1 (low-SES people benefit more). CVD: Cardiovascular health/disease. Gen health: General health. Figure S8. First sensitivity analysis: Effect modification (EM) for race/ethnicity classified by health outcome type. 
EM was recoded as -1 (White people benefit more), 0 (no differences), or 1 (non-White people benefit more). Figure S9. First sensitivity analysis: Effect modification (EM) for SES classified by continent. EM was recoded as -1 (high-SES people benefit more), 0 (no differences), or 1 (low-SES people benefit more). Figure S10. First sensitivity analysis: Effect modification (EM) for race/ethnicity classified by continent. EM was recoded as -1 (White people benefit more), 0 (no differences), or 1 (non-White people benefit more).

Author Contributions: Conceptualization, A.R. and M.H.E.M.B.; methodology, A.R. and M.H.E.M.B.; formal analysis, A.R. and M.H.E.M.B.; data curation, A.R., M.H.E.M.B., O.M., and H.Y.; writingoriginal draft preparation, A.R. and M.H.E.M.B.; writing-review and editing, A.R., M.H.E.M.B., O.M., and H.Y.; visualization, A.R. All authors have read and agreed to the published version of the manuscript.

Funding: This research received no external funding.

Institutional Review Board Statement: Not applicable.

Informed Consent Statement: Not applicable.

Data Availability Statement: Data available upon request.

Conflicts of Interest: The authors declare no conflict of interest.

\section{References}

1. Braveman, P.A.; Arkin, E.; Orleans, T.; Proctor, D.; Plough, A. What is Health Equity? And What Difference Does a Definition Make? Robert Wood Johnson Foundation: Princeton, NJ, USA, 2017.

2. Weinstein, J.N.; Geller, A.; Negussie, Y.; Baciu, A. Communities in Action: Pathways to Health Equity; The National Academies Press: Washington, DC, USA, 2017.

3. OECD. Healthy for Everyone? Social Inequalities in Health and Health Systems; OECD Publishing: Paris, France, 2019; ISBN 9789264731608.

4. Braveman, P.A.; Cubbin, C.; Egerter, S.; Williams, D.R.; Pamuk, E. Socioeconomic disparities in health in the United States: What the patterns tell us. Am. J. Public Health 2010, 100, S186-S196. [CrossRef]

5. Mears, M.; Brindley, P.; Jorgensen, A.; Maheswaran, R. Population-level linkages between urban greenspace and health inequality: The case for using multiple indicators of neighbourhood greenspace. Heal. Place 2020, 62, 102284. [CrossRef]

6. Woolf, B.S.H.; Braveman, P. Where health disparities begin: The role of social and economic determinants-and why current policies may make matters worse. Health Aff. 2011, 30, 1852-1859. [CrossRef]

7. Hero, J.O.; Zaslavsky, A.M.; Blendon, R.J. The United States leads other nations in differences by income in perceptions of health and health care. Health Aff. 2017, 36, 1032-1040. [CrossRef]

8. National Center for Health Statistics. United States Health, 2015-With Special Feature on Racial and Ethnic Health Disparities; Centers for Disease Control and Prevention: Washington, DC, USA, 2016; ISBN 0002-9165.

9. Evandrou, M.; Falkingham, J.; Feng, Z.; Vlachantoni, A. Ethnic inequalities in limiting health and self-reported health in later life revisited. J. Epidemiol. Community Health 2016, 70, 653-662. [CrossRef]

10. Australian Institute of Health and Welfare. Australia's Health 2020: Data Insights; Australian Institute of Health and Welfare: Canberra, Australia, 2020; ISBN 9781760546892.

11. Obuaku-Igwe, C.C. Health inequality in South Africa: A systematic review. African Sociol. Rev. 2015, 19, 96-131.

12. Katz, A.S.; Cheff, R.M.; O'Campo, P. Bringing stakeholders together for urban health equity: Hallmarks of a compromised process. Int. J. Equity Health 2015, 14, 138. [CrossRef]

13. Rouvinen-Wilenius, P.; Ahokas, J.; Kiukas, V.; Aalto-Kallio, M. Finnish NGOs promoting health equity in the context of welfare economy. Health Promot. Int. 2019, 34, 648-657. [CrossRef]

14. Van den Bosch, M.; Ode Sang, A. Urban natural environments as nature-based solutions for improved public health-A systematic review of reviews. Environ. Res. 2017, 158, 373-384. [CrossRef] [PubMed]

15. Twohig-Bennett, C.; Jones, A. The health benefits of the great outdoors: A systematic review and meta-analysis of greenspace exposure and health outcomes. Environ. Res. 2018, 166, 628-637. [CrossRef] [PubMed]

16. Krefis, A.; Augustin, M.; Schlünzen, K.; Oßenbrügge, J.; Augustin, J. How does the urban environment affect health and well-being? A systematic review. Urban. Sci. 2018, 2, 21. [CrossRef]

17. Akaraci, S.; Feng, X.; Suesse, T.; Jalaludin, B.; Astell-Burt, T. A systematic review and meta-analysis of associations between green and blue spaces and birth outcomes. Int. J. Environ. Res. Public Health 2020, 17, 2949. [CrossRef] [PubMed]

18. Rojas-Rueda, D.; Nieuwenhuijsen, M.; Gascon, M.; Perez-Leon, D.; Mudu, P. Green spaces and mortality: A systematic review and meta-analysis of cohort studies I Manuscript Draft. Lancet Planet. Heal. 2019, 19, e469-e477. [CrossRef]

19. Markevych, I.; Schoierer, J.; Hartig, T.; Chudnovsky, A.; Hystad, P.; Dzhambov, A.M.; de Vries, S.; Triguero-Mas, M.; Brauer, M.; Nieuwenhuijsen, M.J.; et al. Exploring pathways linking greenspace to health: Theoretical and methodological guidance. Environ. Res. 2017, 158, 301-317. [CrossRef] 
20. Dzhambov, A.M.; Browning, M.H.E.M.; Markevych, I.; Hartig, T.; Lercher, P. Analytical approaches to testing pathways linking greenspace to health: A scoping review of the empirical literature. Environ. Res. 2020, 186, 109613. [CrossRef] [PubMed]

21. Cole, H.V.S.; Triguero-Mas, M.; Connolly, J.J.T.; Anguelovski, I. Determining the health benefits of green space: Does gentrification matter? Health Place 2019, 57, 1-11. [CrossRef]

22. Feng, X.; Astell-Burt, T. Do greener areas promote more equitable child health? Heal. Place 2017, 46, 267-273. [CrossRef]

23. Ward Thompson, C.; Roe, J.; Aspinall, P.; Mitchell, R.; Clow, A.; Miller, D. More green space is linked to less stress in deprived communities: Evidence from salivary cortisol patterns. Landsc. Urban. Plan. 2012, 105, 221-229. [CrossRef]

24. Osborne Jelks, N.; Jennings, V.; Rigolon, A. Green gentrification and health: A scoping review. Int. J. Environ. Res. Public Health 2021, 18, 907. [CrossRef]

25. Frumkin, H.; Bratman, G.N.; Brewslow, S.J.; Cochran, B.; Kahn, P.H.; Lawler, J.J.; Levin, P.S.; Tandon, P.S.; Varanasi, U.; Wolf, K.L.; et al. Nature contact and human health: A research agenda. Environ. Heal. Perspect. 2017, 125, 075001. [CrossRef]

26. Shanahan, D.F.; Lin, B.B.; Bush, R.; Gaston, K.J.; Dean, J.H.; Barber, E.; Fuller, R.A. Toward improved public health outcomes from urban nature. Am. J. Public Health 2015, 105, 470-477. [CrossRef] [PubMed]

27. Hartig, T.; Mitchell, R.; De Vries, S.; Frumkin, H. Nature and health. Annu. Rev. Public Health 2014, 35, 207-228. [CrossRef] [PubMed]

28. Kabisch, N. The influence of socio-economic and socio-demographic factors in the association between urban green space and health. In Biodiversity and Health in the Face of Climate Change; Springer: Cham, Switzerland, 2019; pp. 91-119. ISBN 9783030023171.

29. James, P.; Banay, R.F.; Hart, J.E.; Laden, F. A review of the health benefits of greenness. Curr. Epidemiol. Reports 2015, 2, 131-142. [CrossRef] [PubMed]

30. Fong, K.C.; Hart, J.E.; James, P. A review of epidemiologic studies on greenness and health: Updated literature through 2017. Curr. Environ. Heal. Reports 2018, 5, 77-87. [CrossRef]

31. Banay, R.F.; Bezold, C.P.; James, P.; Hart, J.E.; Laden, F. Residential greenness: Current perspectives on its impact on maternal health and pregnancy outcomes. Int. J. Womens. Health 2017, 9, 133-144. [CrossRef]

32. Rigolon, A. A complex landscape of inequity in access to urban parks: A literature review. Landsc. Urban. Plan. 2016, 153, 160-169. [CrossRef]

33. Rigolon, A.; Browning, M.H.E.M.; Lee, K.; Shin, S. Access to urban green space in cities of the Global South: A systematic literature review. Urban. Sci. 2018, 2, 67. [CrossRef]

34. Schüle, S.A.; Hilz, L.K.; Dreger, S.; Bolte, G. Social inequalities in environmental resources of green and blue spaces: A review of evidence in the WHO European region. Int. J. Environ. Res. Public Health 2019, 16, 1216. [CrossRef]

35. Wolch, J.R.; Byrne, J.; Newell, J.P. Urban green space, public health, and environmental justice: The challenge of making cities 'just green enough. ' Landsc. Urban. Plan. 2014, 125, 234-244. [CrossRef]

36. Giles-Corti, B.; Vernez-Moudon, A.; Reis, R.; Turrell, G.; Dannenberg, A.L.; Badland, H.; Foster, S.; Lowe, M.; Sallis, J.F.; Stevenson, M.; et al. City planning and population health: A global challenge. Lancet 2016, 388, 2912-2924. [CrossRef]

37. Corburn, J. Confronting the challenges in reconnecting urban planning and public health. Am. J. Public Health 2004, 94, 541-546. [CrossRef]

38. Allen, J.; Balfour, R. Natural Solutions for Tackling Health Inequalities: Realising the Opportunity; UCL Institute of Health Equity: London, UK, 2014.

39. Robinson, O.; Tamayo, I.; de Castro, M.; Valentin, A.; Giorgis-Allemand, L.; Hjertager Krog, N.; Maitre, L.; McEachan, R.; Lepeule, J.; Ambros, A.; et al. The urban exposome during pregnancy and its socioeconomic determinants. Environ. Health Perspect. 2018, 126, 077005. [CrossRef]

40. Robinette, J.W.; Charles, S.T.; Gruenewald, T.L. Neighborhood socioeconomic status and health: A longitudinal analysis. J. Community Health 2017, 42, 865-871. [CrossRef]

41. Marmot, M.; Friel, S.; Bell, R.; Houweling, T.A.; Taylor, S. Closing the gap in a generation: Health equity through action on the social determinants of health. Lancet 2008, 372, 1661-1669. [CrossRef]

42. Ruijsbroek, A.; Droomers, M.; Kruize, H.; Van Kempen, E.; Gidlow, C.J.; Hurst, G.; Andrusaityte, S.; Nieuwenhuijsen, M.J.; Maas, J.; Hardyns, W.; et al. Does the health impact of exposure to neighbourhood green space differ between population groups? An explorative study in four European cities. Int. J. Environ. Res. Public Health 2017, 14, 618. [CrossRef] [PubMed]

43. Maas, J.; Verheij, R.A.; Spreeuwenberg, P.; Groenewegen, P.P. Physical activity as a possible mechanism behind the relationship between green space and health: A multilevel analysis. BMC Public Health 2008, 8, 206. [CrossRef]

44. Loukaitou-Sideris, A.; Stieglitz, O. Children in Los Angeles parks: A study of equity, quality and children's satisfaction with neighbourhood parks. Town Plan. Rev. 2002, 73, 467-488. [CrossRef]

45. Romero, A.J. Low-income neighborhood barriers and resources for adolescents' physical activity. J. Adolesc. Heal. 2005, 36, 253-259. [CrossRef]

46. Cutts, B.B.; Darby, K.J.; Boone, C.G.; Brewis, A. City structure, obesity, and environmental justice: An integrated analysis of physical and social barriers to walkable streets and park access. Soc. Sci. Med. 2009, 69, 1314-1322. [CrossRef]

47. Williams, T.G.; Logan, T.M.; Zuo, C.T.; Liberman, K.D.; Guikema, S.D. Parks and safety: A comparative study of green space access and inequity in five US cities. Landsc. Urban. Plan. 2020, 201, 103841. [CrossRef]

48. Bai, H.; Stanis, S.A.W.; Kaczynski, A.T.; Besenyi, G.M. Perceptions of neighborhood park quality: Associations with physical activity and body mass index. Ann. Behav. Med. 2013, 45, 39-48. [CrossRef] 
49. Cohen, D.A.; Han, B.; Nagel, C.J.; Harnik, P.; McKenzie, T.L.; Evenson, K.R.; Marsh, T.; Williamson, S.; Vaughan, C.; Katta, S. The first national study of neighborhood parks: Implications for physical activity. Am. J. Prev. Med. 2016, 51, 419-426. [CrossRef] [PubMed]

50. Coen, S.E.; Ross, N.A. Exploring the material basis for health: Characteristics of parks in Montreal neighborhoods with contrasting health outcomes. Heal. Place 2006, 4, 361-371. [CrossRef]

51. Mackenbach, J.P.; Valverde, J.R.; Artnik, B.; Bopp, M.; Brønnum-Hansen, H.; Deboosere, P.; Kalediene, R.; Kovács, K.; Leinsalu, M.; Martikainen, P.; et al. Trends in health inequalities in 27 European countries. Proc. Natl. Acad. Sci. USA 2018, 115, 6440-6445. [CrossRef] [PubMed]

52. Whitehead, M. The concepts and principles of equity and health. Int. J. Heal. Serv. 1992, 22, 429-445. [CrossRef]

53. European Commission. Report on Health Inequalities in the European Union; European Commission: Brussels, Belgium, 2013.

54. Tessum, C.W.; Apte, J.S.; Goodkind, A.L.; Muller, N.Z.; Mullins, K.A.; Paolella, D.A.; Polasky, S.; Springer, N.P.; Thakrar, S.K.; Marshall, J.D.; et al. Inequity in consumption widens racial-ethnic disparities in air pollution exposure. Proc. Natl. Acad. Sci. USA 2019, 116, 6001-6006. [CrossRef]

55. WHO Regional Office for Europe Environment and Health Risks: A Review of the Influence and Effects of Social Inequalities; World Health Organization: Copenhagen, Denmark, 2010.

56. Clark, L.P.; Millet, D.B.; Marshall, J.D. National patterns in environmental injustice and inequality: Outdoor $\mathrm{NO}_{2}$ air pollution in the United States. PLoS ONE 2014, 9, e94431. [CrossRef]

57. Williams, D.R.; Lawrence, J.A.; Davis, B.A. Racism and health: Evidence and needed research. Annu. Rev. Public Health 2019, 40, 105-125. [CrossRef]

58. Bailey, Z.D.; Krieger, N.; Agénor, M.; Graves, J.; Linos, N.; Bassett, M.T. Structural racism and health inequities in the USA: Evidence and interventions. Lancet 2017, 389, 1453-1463. [CrossRef]

59. Jennings, V.; Baptiste, A.K.; Osborne Jelks, N.; Skeete, R. Urban green space and the pursuit of health equity in parts of the United States. Int. J. Environ. Res. Public Health 2017, 14, 1432. [CrossRef] [PubMed]

60. Isaacs, K.P.; Choudhury, S. The Growing Gap in Life Expectancy by Income: Recent Evidence and Implications for the Social Security Retirement Age; Congressional Research Service: Washington, DC, USA, 2017.

61. Solé-Auró, A.; Crimmins, E.M. Health of immigrants in European countries. Int. Migr. Rev. 2008, 42, 861-876. [CrossRef]

62. Snijder, M.B.; Galenkamp, H.; Prins, M.; Derks, E.M.; Peters, R.J.G.; Zwinderman, A.H.; Stronks, K. Cohort profile: The Healthy Life in an Urban Setting (HELIUS) study in Amsterdam, the Netherlands. BMJ Open 2017, 7, e017873. [CrossRef] [PubMed]

63. Wang, Y.J.; Chen, X.P.; Chen, W.J.; Zhang, Z.L.; Zhou, Y.P.; Jia, Z. Ethnicity and health inequalities: An empirical study based on the 2010 China survey of social change (CSSC) in Western China. BMC Public Health 2020, 20, 637. [CrossRef]

64. Morgen, C.S.; Bjørk, C.; Andersen, P.K.; Mortensen, L.H.; Nybo Andersen, A.M. Socioeconomic position and the risk of preterm birth-A study within the Danish National Birth Cohort. Int. J. Epidemiol. 2008, 37, 1109-1120. [CrossRef] [PubMed]

65. Benatar, S. The challenges of health disparities in South Africa. S. Afr. Med. J. 2013, 103, 154-155. [CrossRef]

66. Moher, D.; Liberati, A.; Tetzlaff, J.; Altman, D.G.; Altman, D.; Antes, G.; Atkins, D.; Barbour, V.; Barrowman, N.; Berlin, J.A.; et al. Preferred reporting items for systematic reviews and meta-analyses: The PRISMA statement. PLoS Med. 2009, 6, e1000097. [CrossRef] [PubMed]

67. Jennings, V.; Browning, M.H.E.M.; Rigolon, A. Urban. Green Spaces—Public Health and Sustainabilty in the United States; Springer: Basel, Switzerland, 2019.

68. Browning, M.H.E.M.; Rigolon, A. School green space and its impact on academic performance: A systematic literature review. Int. J. Environ. Res. Public Health 2019, 16, 429. [CrossRef] [PubMed]

69. Collins, R.M.; Spake, R.; Brown, K.A.; Ogutu, B.O.; Smith, D.; Eigenbrod, F. A systematic map of research exploring the effect of greenspace on mental health. Landsc. Urban. Plan. 2020, 201, 103823. [CrossRef]

70. Taylor, L.; Hochuli, D.F. Defining greenspace: Multiple uses across multiple disciplines. Landsc. Urban. Plan. 2017, 158, 25-38. [CrossRef]

71. Labib, S.M.; Lindley, S.; Huck, J.J. Scale effects in remotely sensed greenspace metrics and how to mitigate them for environmental health exposure assessment. Comput. Environ. Urban. Syst. 2020, 82, 101501. [CrossRef]

72. Helbich, M.; O'Connor, R.C.; Nieuwenhuijsen, M.; Hagedoorn, P. Greenery exposure and suicide mortality later in life: A longitudinal register-based case-control study. Environ. Int. 2020, 143, 105982. [CrossRef]

73. Lahart, I.; Darcy, P.; Gidlow, C.; Calogiuri, G. The effects of green exercise on physical and mental wellbeing: A systematic review. Int. J. Environ. Res. Public Health 2019, 16, 1352. [CrossRef]

74. Son, J.Y.; Liu, J.C.; Bell, M.L. Temperature-related mortality: A systematic review and investigation of effect modifiers. Environ. Res. Lett. 2019, 14, 073004. [CrossRef]

75. Radke, E.G.; Glenn, B.; Galizia, A.; Persad, A.; Nachman, R.; Bateson, T.; Wright, J.M.; Navas-Acien, A.; Arroyave, W.D.; Puett, R.C.; et al. Development of outcome-specific criteria for study evaluation in systematic reviews of epidemiology studies. Environ. Int. 2019, 130, 104884. [CrossRef] [PubMed]

76. Radke, E.G.; Braun, J.M.; Nachman, R.M.; Cooper, G.S. Phthalate exposure and neurodevelopment: A systematic review and meta-analysis of human epidemiological evidence. Environ. Int. 2020, 137, 105408. [CrossRef] [PubMed]

77. R Core Team. R: A Language and Environment for Statistical Computing; R Core Team: Vienna, Austria, 2020. 
78. Leech, N.L.; Barrett, K.C.; Morgan, G.A. IBM SPSS for Intermediate Statistics: Use and Interpretation, 4th ed.; Routledge: New York, NY, USA, 2011.

79. Maxwell, S.E.; Delaney, H.D. Designing Experiments and Analyzing Data: A Model. Comparison Perspective, 2nd ed.; Psychology Press: New York, NY, USA, 2004.

80. Hsu, J.C. Multiple Comparisons: Theory and Methods; Chapman \& Hall/CRC: Boca Raton, FL, USA, 1996.

81. West, L.J.; Hankin, R.K.S. Exact tests for two-way contingency tables with structural zeros. J. Stat. Softw. 2008, 28, 1-19. [CrossRef]

82. Talen, E. Neighborhoods as service providers: A methodology for evaluating pedestrian access. Environ. Plan. B Plan. Des. 2003, 30, 181-200. [CrossRef]

83. Labib, S.M.; Lindley, S.; Huck, J.J. Spatial dimensions of the influence of urban green-blue spaces on human health: A systematic review. Environ. Res. 2020, 180, 108869. [CrossRef]

84. Abelt, K.; McLafferty, S. Green streets: Urban green and birth outcomes. Int. J. Environ. Res. Public Health 2017, 14, 771. [CrossRef]

85. Agay-Shay, K.; Peled, A.; Crespo, A.V.; Peretz, C.; Amitai, Y.; Linn, S.; Friger, M.; Nieuwenhuijsen, M.J. Green spaces and adverse pregnancy outcomes. Occup. Environ. Med. 2014, 71, 562-569. [CrossRef]

86. Agay-Shay, K.; Michael, Y.; Basagaña, X.; Martínez-Solanas, È.; Broday, D.; Lensky, I.M.; Rudolf, M.; Rubin, L.; Kent, R.; Levy, N.; et al. Mean and variance of greenness and pregnancy outcomes in Tel Aviv during 2000-14: Longitudinal and cross-sectional approaches. Int. J. Epidemiol. 2019, 48, 1054-1072. [CrossRef]

87. Agyemang, C.; Van Hooijdonk, C.; Wendel-Vos, W.; Ujcic-Voortman, J.K.; Lindeman, E.; Stronks, K.; Droomers, M. Ethnic differences in the effect of environmental stressors on blood pressure and hypertension in the Netherlands. BMC Public Health 2007, 7, 118. [CrossRef] [PubMed]

88. Alexander, D.S.; Huber, L.R.B.; Piper, C.R.; Tanner, A.E. The association between recreational parks, facilities and childhood obesity: A cross-sectional study of the 2007 National Survey of Children's Health. J. Epidemiol. Community Health 2013, 67, 427-431. [CrossRef] [PubMed]

89. Astell-Burt, T.; Feng, X.; Kolt, G.S. Is neighborhood green space associated with a lower risk of type 2 diabetes? Evidence from 267,072 Australians. Diabetes Care 2014, 37, 197-201. [CrossRef] [PubMed]

90. Björk, J.; Albin, M.; Grahn, P.; Jacobsson, H.; Ardö, J.; Wadbro, J.; Ostergren, P.O. Recreational values of the natural environment in relation to neighbourhood satisfaction, physical activity, obesity and wellbeing. J. Epidemiol. Community Health 2008, 62, e2. [CrossRef] [PubMed]

91. Brindley, P.; Jorgensen, A.; Maheswaran, R. Domestic gardens and self-reported health: A national population study. Int. J. Health Geogr. 2018, 17, 31. [CrossRef] [PubMed]

92. Brown, S.C.; Lombard, J.; Wang, K.; Byrne, M.M.; Toro, M.; Plater-Zyberk, E.; Feaster, D.J.; Kardys, J.; Nardi, M.I.; Perez-Gomez, G.; et al. Neighborhood greenness and chronic health conditions in medicare beneficiaries. Am. J. Prev. Med. 2016, 51, 78-89. [CrossRef] [PubMed]

93. Browning, M.H.E.M.; Rigolon, A. Do income, race and ethnicity, and sprawl influence the greenspace-human health link in city-level analyses? Findings from 496 cities in the United States. Int. J. Environ. Res. Public Health 2018, 15, 1541. [CrossRef]

94. Casey, J.A.; James, P.; Rudolph, K.E.; Wu, C.D.; Schwartz, B.S. Greenness and birth outcomes in a range of Pennsylvania communities. Int. J. Environ. Res. Public Health 2016, 13, 311. [CrossRef]

95. Coppel, G.; Wüstemann, H. The impact of urban green space on health in Berlin, Germany: Empirical findings and implications for urban planning. Landsc. Urban. Plan. 2017, 167, 410-418. [CrossRef]

96. Crouse, D.L.; Pinault, L.; Balram, A.; Hystad, P.; Peters, P.A.; Chen, H.; van Donkelaar, A.; Martin, R.V.; Ménard, R.; Robichaud, A.; et al. Urban greenness and mortality in Canada's largest cities: A national cohort study. Lancet Planet. Heal. 2017, 1, e289-e297. [CrossRef]

97. Cummins, S.; Fagg, J. Does greener mean thinner? Associations between neighbourhood greenspace and weight status among adults in England. Int. J. Obes. 2012, 36, 1108-1113. [CrossRef]

98. Cusack, L.; Larkin, A.; Carozza, S.E.; Hystad, P. Associations between multiple green space measures and birth weight across two US cities. Heal. Place 2017, 47, 36-43. [CrossRef] [PubMed]

99. Cusack, L.; Larkin, A.; Carozza, S.E.; Hystad, P. Associations between residential greenness and birth outcomes across Texas. Environ. Res. 2017, 152, 88-95. [CrossRef] [PubMed]

100. Cusack, L.; Sbihi, H.; Larkin, A.; Chow, A.; Brook, J.R.; Moraes, T.; Mandhane, P.J.; Becker, A.B.; Azad, M.B.; Subbarao, P.; et al. Residential green space and pathways to term birth weight in the Canadian Healthy Infant Longitudinal Development (CHILD) Study. Int. J. Health Geogr. 2018, 17, 43. [CrossRef] [PubMed]

101. Da Silveira, I.H.; Junger, W.L. Green spaces and mortality due to cardiovascular diseases in the city of Rio de Janeiro. Rev. Saude Publica 2018, 52, 49. [CrossRef]

102. Dadvand, P.; de Nazelle, A.; Figueras, F.; Basagaña, X.; Su, J.; Amoly, E.; Jerrett, M.; Vrijheid, M.; Sunyer, J.; Nieuwenhuijsen, M.J. Green space, health inequality and pregnancy. Environ. Int. 2012, 40, 110-115. [CrossRef]

103. Dadvand, P.; Sunyer, J.; Basagaña, X.; Ballester, F.; Lertxundi, A.; Fernández-Somoano, A.; Estarlich, M.; García-Esteban, R.; Mendez, M.A.; Nieuwenhuijsen, M.J. Surrounding greenness and pregnancy outcomes in four Spanish birth cohorts. Environ. Health Perspect. 2012, 120, 1481-1487. [CrossRef] 
104. Dadvand, P.; Villanueva, C.M.; Font-Ribera, L.; Martinez, D.; Basagaña, X.; Belmonte, J.; Vrijheid, M.; Gražuleviciene, R.; Kogevinas, M.; Nieuwenhuijsen, M.J. Risks and benefits of green spaces for children: A cross-sectional study of associations with sedentary behavior, obesity, asthma, and allergy. Environ. Health Perspect. 2014, 122, 1329-1336. [CrossRef]

105. Dadvand, P.; Wright, J.; Martinez, D.; Basagaña, X.; McEachan, R.R.C.; Cirach, M.; Gidlow, C.J.; de Hoogh, K.; Gražulevičienè, R.; Nieuwenhuijsen, M.J. Inequality, green spaces, and pregnant women: Roles of ethnicity and individual and neighbourhood socioeconomic status. Environ. Int. 2014, 71, 101-108. [CrossRef]

106. Dadvand, P.; Poursafa, P.; Heshmat, R.; Motlagh, M.E.; Qorbani, M.; Basagaña, X.; Kelishadi, R. Use of green spaces and blood glucose in children; a population-based CASPIAN-V study. Environ. Pollut. 2018, 243, 1134-1140. [CrossRef] [PubMed]

107. D'Agostino, E.M.; Patel, H.H.; Ahmed, Z.; Hansen, E.; Sunil Mathew, M.; Nardi, M.I.; Messiah, S.E. Impact of change in neighborhood racial/ethnic segregation on cardiovascular health in minority youth attending a park-based afterschool program. Soc. Sci. Med. 2018, 205, 116-129. [CrossRef] [PubMed]

108. D'Agostino, E.M.; Patel, H.H.; Hansen, E.; Mathew, M.S.; Nardi, M.; Messiah, S.E. Longitudinal analysis of cardiovascular disease risk profile in neighbourhood poverty subgroups: 5-year results from an afterschool fitness programme in the USA. J. Epidemiol. Community Health 2018, 72, 193-201. [CrossRef]

109. Dalton, A.M.; Jones, A.P.; Sharp, S.J.; Cooper, A.J.M.; Griffin, S.; Wareham, N.J. Residential neighbourhood greenspace is associated with reduced risk of incident diabetes in older people: A prospective cohort study. BMC Public Health 2016, 16, 1171. [CrossRef]

110. De Keijzer, C.; Agis, D.; Ambrós, A.; Arévalo, G.; Baldasano, J.M.; Bande, S.; Barrera-Gómez, J.; Benach, J.; Cirach, M.; Dadvand, P.; et al. The association of air pollution and greenness with mortality and life expectancy in Spain: A small-area study. Environ. Int. 2017, 99, 170-176. [CrossRef]

111. De Vries, S.; Verheij, R.A.; Groenewegen, P.P.; Spreeuwenberg, P. Natural environments-Healthy environments? An exploratory analysis of the relationship between greenspace and health. Environ. Plan. A 2003, 35, 1717-1731. [CrossRef]

112. Demoury, C.; Thierry, B.; Richard, H.; Sigler, B.; Kestens, Y.; Parent, M.E. Residential greenness and risk of prostate cancer: A case-control study in Montreal, Canada. Environ. Int. 2017, 98, 129-136. [CrossRef]

113. Donovan, G.H.; Butry, D.T.; Michael, Y.L.; Prestemon, J.P.; Liebhold, A.M.; Gatziolis, D.; Mao, M.Y. The relationship between trees and human health: Evidence from the spread of the emerald ash borer. Am. J. Prev. Med. 2013, 44, 139-145. [CrossRef]

114. Donovan, G.H.; Gatziolis, D.; Longley, I.; Douwes, J. Vegetation diversity protects against childhood asthma: Results from a large New Zealand birth cohort. Nat. Plants 2018, 4, 358-364. [CrossRef] [PubMed]

115. Dzhambov, A.M.; Markevych, I.; Lercher, P. Greenspace seems protective of both high and low blood pressure among residents of an Alpine valley. Environ. Int. 2018, 121, 443-452. [CrossRef] [PubMed]

116. Ebisu, K.; Holford, T.R.; Bell, M.L. Association between greenness, urbanicity, and birth weight. Sci. Total Environ. 2016, 542, 750-756. [CrossRef]

117. Egorov, A.I.; Griffin, S.M.; Converse, R.R.; Styles, J.N.; Sams, E.A.; Wilson, A.; Jackson, L.E.; Wade, T.J. Vegetated land cover near residence is associated with reduced allostatic load and improved biomarkers of neuroendocrine, metabolic and immune functions. Environ. Res. 2017, 158, 508-521. [CrossRef]

118. Eldeirawi, K.; Kunzweiler, C.; Zenk, S.; Finn, P.; Nyenhuis, S.; Rosenberg, N.; Persky, V. Associations of urban greenness with asthma and respiratory symptoms in Mexican American children. Ann. Allergy Asthma Immunol. 2019, 122, 289-295. [CrossRef]

119. Fan, M.; Jin, Y. Do neighborhood parks and playgrounds reduce childhood obesity? Am. J. Agric. Econ. 2014, 96, 26-42. [CrossRef]

120. Fong, K.C.; Kloog, I.; Coull, B.A.; Koutrakis, P.; Laden, F.; Schwartz, J.D.; James, P. Residential greenness and birthweight in the state of Massachusetts, USA. Int. J. Environ. Res. Public Health 2018, 15, 1248. [CrossRef] [PubMed]

121. Foster, B.A.; Weinstein, K. Moderating effects of components of resilience on obesity across income strata in the National Survey of Children's Health. Acad. Pediatr. 2019, 19, 58-66. [CrossRef] [PubMed]

122. Gidlow, C.J.; Smith, G.; Martinez, D.; Wilson, R.; Trinder, P.; Gražulevičiene, R.; Nieuwenhuijsen, M.J. Research note: Natural environments and prescribing in England. Landsc. Urban. Plan. 2016, 151, 103-108. [CrossRef]

123. Glazer, K.B.; Eliot, M.N.; Danilack, V.A.; Carlson, L.; Phipps, M.G.; Dadvand, P.; Savitz, D.A.; Wellenius, G.A. Residential green space and birth outcomes in a coastal setting. Environ. Res. 2018, 163, 97-107. [CrossRef]

124. Groenewegen, P.P.; Zock, J.P.; Spreeuwenberg, P.; Helbich, M.; Hoek, G.; Ruijsbroek, A.; Strak, M.; Verheij, R.; Volker, B.; Waverijn, G.; et al. Neighbourhood social and physical environment and general practitioner assessed morbidity. Heal. Place 2018, 49, 68-84. [CrossRef] [PubMed]

125. Hobbs, M.; Green, M.A.; Griffiths, C.; Jordan, H.; Saunders, J.; Grimmer, H.; McKenna, J. Access and quality of parks and associations with obesity: A cross-sectional study. SSM Popul. Heal. 2017, 3, 722-729. [CrossRef] [PubMed]

126. Hobbs, M.; Griffiths, C.; Green, M.A.; Jordan, H.; Saunders, J.; McKenna, J. Associations between the combined physical activity environment, socioeconomic status, and obesity: A cross-sectional study. Perspect. Public Health 2018, 138, 169-172. [CrossRef]

127. Hughey, S.M.; Kaczynski, A.T.; Child, S.; Moore, J.B.; Porter, D.; Hibbert, J. Green and lean: Is neighborhood park and playground availability associated with youth obesity? Variations by gender, socioeconomic status, and race/ethnicity. Prev. Med. 2017, 95, S101-S108. [CrossRef] [PubMed]

128. Hystad, P.; Davies, H.W.; Frank, L.; Van Loon, J.; Gehring, U.; Tamburic, L.; Brauer, M. Residential Greenness and Birth Outcomes: Evaluating the Influence of Spatially Correlated Built-Environment Factors. Environ. Health Perspect. 2014, 122, $1095-1102$. [CrossRef] [PubMed] 
129. James, P.; Hart, J.E.; Banay, R.F.; Laden, F. Exposure to greenness and mortality in a nationwide prospective cohort study of women. Environ. Health Perspect. 2016, 124, 1344-1352. [CrossRef]

130. Ji, J.S.; Zhu, A.; Bai, C.; Wu, C.D.; Yan, L.; Tang, S.; Zeng, Y.; James, P. Residential greenness and mortality in oldest-old women and men in China: A longitudinal cohort study. Lancet Planet. Heal. 2019, 3, e17-e25. [CrossRef]

131. Jilcott Pitts, S.B.; Edwards, M.B.; Moore, J.B.; Shores, K.A.; Dubose Drowatzky, K.; McGranahan, D. Obesity is inversely associated with natural amenities and recreation facilities per capita. J. Phys. Act. Health 2013, 10, 1032-1038. [CrossRef]

132. Kihal-Talantikite, W.; Padilla, C.M.; Lalloué, B.; Gelormini, M.; Zmirou-Navier, D.; Deguen, S. Green space, social inequalities and neonatal mortality in France. BMC Pregnancy Childbirth 2013, 13, 191. [CrossRef] [PubMed]

133. Kling, H.E.; D'Agostino, E.M.; Booth, J.V.; Patel, H.; Hansen, E.; Mathew, M.S.; Messiah, S.E. The effect of a park-based physical activity program on cardiovascular, strength, and mobility outcomes among a sample of racially/ethnically diverse adults aged 55 or older. Prev. Chronic Dis. 2018, 15, E166. [CrossRef]

134. Lachowycz, K.; Jones, A.P. Does walking explain associations between access to greenspace andlower mortality? Soc. Sci. Med. 2014, 107, 9-17. [CrossRef]

135. Lovasi, G.S.; Bader, M.D.M.; Quinn, J.; Neckerman, K.M.; Weiss, C.; Rundle, A. Body mass index, safety hazards, and neighborhood attractiveness. Am. J. Prev. Med. 2012, 43, 378-384. [CrossRef]

136. Maas, J.; Verheij, R.A.; Groenewegen, P.P.; De Vries, S.; Spreeuwenberg, P.P. Green space, urbanity, and health: How strong is the relation? J. Epidemiol. Community Health 2006, 60, 587-592. [CrossRef] [PubMed]

137. Maas, J.; Verheij, R.A.; De Vries, S.; Spreeuwenberg, P.; Schellevis, F.G.; Groenewegen, P.P. Morbidity is related to a green living environment. J. Epidemiol. Community Health 2009, 63, 967-973. [CrossRef] [PubMed]

138. Markevych, I.; Fuertes, E.; Tiesler, C.M.T.; Birk, M.; Bauer, C.P.; Koletzko, S.; von Berg, A.; Berdel, D.; Heinrich, J. Surrounding greenness and birth weight: Results from the GINIplus and LISAplus birth cohorts in Munich. Heal. Place 2014, 26, 39-46. [CrossRef] [PubMed]

139. Mena, C.; Fuentes, E.; Ormazábal, Y.; Palomo-Vélez, G.; Palomo, I. Role of access to parks and markets with anthropometric measurements, biological markers, and a healthy lifestyle. Int. J. Environ. Health Res. 2015, 25, 373-383. [CrossRef]

140. Mitchell, R.; Popham, F. Effect of exposure to natural environment on health inequalities: An observational population study. Lancet 2008, 372, 1655-1660. [CrossRef]

141. Mueller, N.; Rojas-Rueda, D.; Khreis, H.; Cirach, M.; Milà, C.; Espinosa, A.; Foraster, M.; McEachan, R.R.C.; Kelly, B.; Wright, J.; et al. Socioeconomic inequalities in urban and transport planning related exposures and mortality: A health impact assessment study for Bradford, UK. Environ. Int. 2018, 121, 931-941. [CrossRef]

142. Nichani, V.; Dirks, K.; Burns, B.; Bird, A.; Morton, S.; Grant, C. Green space and pregnancy outcomes: Evidence from Growing Up in New Zealand. Heal. Place 2017, 46, 21-28. [CrossRef]

143. Nieuwenhuijsen, M.J.; Gascon, M.; Martinez, D.; Ponjoan, A.; Blanch, J.; Garcia-Gil, M.D.M.; Ramos, R.; Foraster, M.; Mueller, N.; Espinosa, A.; et al. Air pollution, noise, blue space, and green space and premature mortality in Barcelona: A mega cohort. Int. J. Environ. Res. Public Health 2018, 15, 2405. [CrossRef]

144. Orioli, R.; Antonucci, C.; Scortichini, M.; Cerza, F.; Marando, F.; Ancona, C.; Manes, F.; Davoli, M.; Michelozzi, P.; Forastiere, F.; et al. Exposure to residential greenness as a predictor of cause-specific mortality and stroke incidence in the rome longitudinal study. Environ. Health Perspect. 2019, 127, 027002. [CrossRef]

145. Persson, A.; Pyko, A.; Lind, T.; Bellander, T.; Östenson, C.G.; Pershagen, G.; Eriksson, C.; Lõhmus, M. Urban residential greenness and adiposity: A cohort study in Stockholm County. Environ. Int. 2018, 121, 832-841. [CrossRef]

146. Petraviciene, I.; Grazuleviciene, R.; Andrusaityte, S.; Dedele, A.; Nieuwenhuijsen, M.J. Impact of the social and natural environment on preschool-age children weight. Int. J. Environ. Res. Public Health 2018, 15, 449. [CrossRef] [PubMed]

147. Pun, V.C.; Manjourides, J.; Suh, H.H. Association of neighborhood greenness with self-perceived stress, depression and anxiety symptoms in older U.S adults. Environ. Heal. A Glob. Access Sci. Source 2018, 17, 39. [CrossRef] [PubMed]

148. Reid, C.E.; Clougherty, J.E.; Shmool, J.L.C.; Kubzansky, L.D. Is all urban green space the same? A comparison of the health benefits of trees and grass in New York city. Int. J. Environ. Res. Public Health 2017, 14, 1411. [CrossRef] [PubMed]

149. Richardson, E.A.; Shortt, N.K.; Mitchell, R.; Pearce, J. A sibling study of whether maternal exposure to different types of natural space is related to birthweight. Int. J. Epidemiol. 2018, 47, 146-155. [CrossRef]

150. Rossi, C.E.; Correa, E.N.; das Neves, J.; Gabriel, C.G.; Benedet, J.; Rech, C.R.; de Assis Guedas de Vasconcelos, F. Body mass index and association with use of and distance from places for physical activity and active leisure among schoolchildren in Brazil. Cross-sectional study. Sao Paulo Med. J. 2018, 136, 228-236. [CrossRef]

151. Rossi, C.E.; De Fragas, H.P.; Corrêa, E.N.; Das Neves, J.; De Assis Guedes De Vasconcelos, F. Association between food, physical activity, and social assistance environments and the body mass index of schoolchildren from different socioeconomic strata. $J$. Public Health 2019, 41, E25-E34. [CrossRef]

152. Sarkar, C. Residential greenness and adiposity: Findings from the UK Biobank. Environ. Int. 2017, 106, 1-10. [CrossRef]

153. Schalkwijk, A.A.H.; Van Der Zwaard, B.C.; Nijpels, G.; Elders, P.J.M.; Platt, L. The impact of greenspace and condition of the neighbourhood on child overweight. Eur. J. Public Health 2018, 28, 88-94. [CrossRef]

154. Schuler, B.R.; O'Reilly, N. Child development and the community environment: Understanding overweight across the income gradient. Child. Obes. 2017, 13, 479-489. [CrossRef] 
155. Seo, S.; Choi, S.; Kim, K.; Kim, S.M.; Park, S.M. Association between urban green space and the risk of cardiovascular disease: A longitudinal study in seven Korean metropolitan areas. Environ. Int. 2019, 125, 51-57. [CrossRef]

156. Singh, G.K.; Siahpush, M.; Kogan, M.D. Neighborhood socioeconomic conditions, built environments, and childhood obesity. Health Aff. 2010, 29, 503-512. [CrossRef]

157. Sullivan, S.M.; Brashear, M.M.; Broyles, S.T.; Rung, A.L. Neighborhood environments and obesity among Afro-Caribbean, African American, and Non-Hispanic white adults in the United States: Results from the National Survey of American Life. Prev. Med. 2014, 61, 1-5. [CrossRef] [PubMed]

158. Thiering, E.; Markevych, I.; Brüske, I.; Fuertes, E.; Kratzsch, J.; Sugiri, D.; Hoffmann, B.; Von Berg, A.; Bauer, C.P.; Koletzko, S.; et al. Associations of residential long-term air pollution exposures and satellite-derived greenness with insulin resistance in German adolescents. Environ. Health Perspect. 2016, 124, 1291-1298. [CrossRef]

159. Triguero-Mas, M.; Dadvand, P.; Cirach, M.; Martínez, D.; Medina, A.; Mompart, A.; Basagaña, X.; Gražulevičiene, R.; Nieuwenhuijsen, M.J. Natural outdoor environments and mental and physical health: Relationships and mechanisms. Environ. Int. 2015, 77, 35-41. [CrossRef]

160. Van Der Zwaard, B.C.; Schalkwijk, A.A.H.; Elders, P.J.M.; Platt, L.; Nijpels, G. Does environment influence childhood BMI? A longitudinal analysis of children aged 3-11. J. Epidemiol. Community Health 2018, 72, 1110-1116. [CrossRef] [PubMed]

161. Vienneau, D.; de Hoogh, K.; Faeh, D.; Kaufmann, M.; Wunderli, J.M.; Röösli, M. The SNC Study Group More than clean air and tranquillity: Residential green is independently associated with decreasing mortality. Environ. Int. 2017, 108, 176-184. [CrossRef] [PubMed]

162. Villeneuve, P.J.; Jerrett, M.; Su, J.G.; Burnett, R.T.; Chen, H.; Wheeler, A.J.; Goldberg, M.S. A cohort study relating urban green space with mortality in Ontario, Canada. Environ. Res. 2012, 115, 51-58. [CrossRef] [PubMed]

163. Villeneuve, P.J.; Jerrett, M.; Su, J.G.; Weichenthal, S.; Sandler, D.P. Association of residential greenness with obesity and physical activity in a US cohort of women. Environ. Res. 2018, 160, 372-384. [CrossRef] [PubMed]

164. Wang, Q.; Lan, Z. Park green spaces, public health and social inequalities: Understanding the interrelationships for policy implications. Land Use Policy 2019, 83, 66-74. [CrossRef]

165. Wen, M.; Kowaleski-Jones, L. The built environment and risk of obesity in the United States: Racial-ethnic disparities. Health Place 2012, 18, 1314-1322. [CrossRef]

166. Wilker, E.H.; Wu, C.D.; McNeely, E.; Mostofsky, E.; Spengler, J.; Wellenius, G.A.; Mittleman, M.A. Green space and mortality following ischemic stroke. Environ. Res. 2014, 133, 42-48. [CrossRef]

167. Wu, J.; Rappazzo, K.M.; Simpson, R.J.; Joodi, G.; Pursell, I.W.; Mounsey, J.P.; Cascio, W.E.; Jackson, L.E. Exploring links between greenspace and sudden unexpected death: A spatial analysis. Environ. Int. 2018, 113, 114-121. [CrossRef]

168. Xu, L.; Ren, C.; Yuan, C.; Nichol, J.E.; Goggins, W.B. An ecological study of the association between area-level green space and adult mortality in Hong Kong. Climate 2017, 5, 55. [CrossRef]

169. Yang, B.-Y.; Markevych, I.; Bloom, M.S.; Heinrich, J.; Guo, Y.; Morawska, L.; Dharmage, S.C.; Knibbs, L.D.; Jalaludin, B.; Jalava, P.; et al. Community greenness, blood pressure, and hypertension in urban dwellers: The 33 Communities Chinese Health Study. Environ. Int. 2019, 126, 727-734. [CrossRef]

170. Yang, B.-Y.; Markevych, I.; Heinrich, J.; Bowatte, G.; Bloom, M.S.; Guo, Y.; Dharmage, S.C.; Jalaludin, B.; Knibbs, L.D.; Morawska, L.; et al. Associations of greenness with diabetes mellitus and glucose-homeostasis markers: The 33 Communities Chinese Health Study. Int. J. Hyg. Environ. Health 2019, 222, 283-290. [CrossRef]

171. Yeager, R.; Riggs, D.W.; DeJarnett, N.; Tollerud, D.J.; Wilson, J.; Conklin, D.J.; O’Toole, T.E.; McCracken, J.; Lorkiewicz, P.; Xie, Z.; et al. Association between residential greenness and cardiovascular disease risk. J. Am. Heart Assoc. 2018, 7, e009117. [CrossRef]

172. Yitshak-Sade, M.; James, P.; Kloog, I.; Hart, J.E.; Schwartz, J.D.; Laden, F.; Lane, K.J.; Fabian, M.P.; Fong, K.C.; Zanobetti, A. Neighborhood greenness attenuates the adverse effect of PM2.5 on cardiovascular mortality in neighborhoods of lower socioeconomic status. Int. J. Environ. Res. Public Health 2019, 16, 814. [CrossRef]

173. Marselle, M.R.; Hartig, T.; Cox, D.T.C.; de Bell, S.; Knapp, S.; Lindley, S.; Triguero-Mas, M.; Böhning-Gaese, K.; Braubach, M.; Cook, P.A.; et al. Pathways linking biodiversity to human health: A conceptual framework. Environ. Int. 2021, 150, 106420. [CrossRef] [PubMed]

174. Chiabai, A.; Quiroga, S.; Martinez-Juarez, P.; Suárez, C.; García de Jalón, S.; Taylor, T. Exposure to green areas: Modeling health benefits in a context of study heterogeneity. Ecol. Econ. 2020, 167, 106401. [CrossRef]

175. Asri, A.K.; Yu, C.P.; Pan, W.C.; Guo, Y.L.; Su, H.J.; Lung, S.C.C.; Wu, C.D.; Spengler, J.D. Global greenness in relation to reducing the burden of cardiovascular diseases: Ischemic heart disease and stroke. Environ. Res. Lett. 2020, 15, 124003. [CrossRef]

176. Jones, A.P.; Brainard, J.; Bateman, I.J.; Lovett, A.A. Equity of access to public parks in Birmingham, England. Environ. Res. J. 2009, 3, 237-256.

177. Jones, A.P.; Hillsdon, M.; Coombes, E. Greenspace access, use, and physical activity: Understanding the effects of area deprivation. Prev. Med. 2009, 49, 500-505. [CrossRef] [PubMed]

178. Cohen, D.A.; Inagami, S.; Finch, B. The built environment and collective efficacy. Heal. Place 2008, 14, 198-208. [CrossRef]

179. Larson, L.R.; Jennings, V.; Cloutier, S.A. Public parks and wellbeing in urban areas of the United States. PLoS ONE 2016, 11, e0153211. [CrossRef]

180. Cronan, M.K.; Shinew, K.J.; Stodolska, M. Trail use among Latinos: Recognizing diverse uses among a specific population. J. Park Recreat. Adm. 2008, 26, 62-86. 
181. Gobster, P.H. Managing urban parks for a racially and ethnically diverse clientele. Leis. Sci. 2002, 24, 143-159. [CrossRef]

182. Hordyk, S.R.; Hanley, J.; Richard, É. "Nature is there; its free": Urban greenspace and the social determinants of health of immigrant families. Heal. Place 2015, 34, 74-82. [CrossRef]

183. Browning, M.H.E.M.; Lee, K. Within what distance does "greenness" best predict physical health? A systematic review of articles with gis buffer analyses across the lifespan. Int. J. Environ. Res. Public Health 2017, 14, 675. [CrossRef]

184. Yang, Y.; Diez-Roux, A.V. Walking distance by trip purpose and population subgroups. Am. J. Prev. Med. 2012, 43, 11-19. [CrossRef] [PubMed]

185. Alesina, A.; Glaeser, E.; Sacerdote, B. Why doesn't the United States have a European-style welfare state? Brook. Pap. Econ. Act. 2001, 2, 187-277. [CrossRef]

186. Harris, B.; Schmalz, D.; Larson, L.R.; Fernandez, M. Fear of the unknown: Examining neighborhood stigma's effect on urban greenway use and surrounding communities. Urban. Aff. Rev. 2020. [CrossRef]

187. Low, S.; Taplin, D.; Scheld, S. Rethinking Urban. Parks: Public Space and Cultural Diversity; University of Texas Press: Austin, TX, USA, 2005.

188. McDaid, D.; Sassi, F.; Merkur, S. (Eds.) Promoting Health and Preventing Disease: The Economic Case; Open University Press: Maidenhead, UK, 2020.

189. EUROPARC Federation Healthy Parks Healthy People Europe. Available online: https://www.europarc.org/nature/healthyparks-healthy-people-europe/ (accessed on 24 July 2020).

190. Garrett, J.K.; Clitherow, T.J.; White, M.P.; Wheeler, B.W.; Fleming, L.E. Coastal proximity and mental health among urban adults in England: The moderating effect of household income. Heal. Place 2019, 59, 102200. [CrossRef]

191. Lambert, K.A.; Bowatte, G.; Tham, R.; Lodge, C.; Prendergast, L.; Heinrich, J.; Abramson, M.J.; Dharmage, S.C.; Erbas, B. Residential greenness and allergic respiratory diseases in children and adolescents-A systematic review and meta-analysis. Environ. Res. 2017, 159, 212-221. [CrossRef] [PubMed]

192. Lambert, K.A.; Bowatte, G.; Tham, R.; Lodge, C.J.; Prendergast, L.A.; Heinrich, J.; Abramson, M.J.; Dharmage, S.C.; Erbas, B. Greenspace and atopic sensitization in children and adolescents-a systematic review. Int. J. Environ. Res. Public Health 2018, 15, 2539. [CrossRef]

193. Markevych, I.; Ludwig, R.; Baumbach, C.; Standl, M.; Heinrich, J.; Herberth, G.; de Hoogh, K.; Pritsch, K.; Weikl, F. Residing near allergenic trees can increase risk of allergies later in life: LISA Leipzig study. Environ. Res. 2020, 191, 110132. [CrossRef] [PubMed]

194. Dzhambov, A.M.; Lercher, P.; Rüdisser, J.; Browning, M.H.E.M.; Markevych, I. Allergic symptoms in association with naturalness, greenness, and greyness: A cross-sectional study in schoolchildren in the Alps. Environ. Res. 2020. [CrossRef] [PubMed]

195. Boone-Heinonen, J.; Gordon-Larsen, P.; Guilkey, D.K.; Jacobs, D.R.; Popkin, B.M. Environment and physical activity dynamics: The role of residential self-selection. Psychol. Sport Exerc. 2011, 12, 54-60. [CrossRef]

196. Cao, X.; Handy, S.L.; Mokhtarian, P.L. The influences of the built environment and residential self-selection on pedestrian behavior: Evidence from Austin, TX. Transportation 2006, 33, 1-20. [CrossRef]

197. Handy, S.; Cao, X.; Mokhtarian, P.L. Self-selection in the relationship between the built environment and walking: Empirical evidence from Northern California. J. Am. Plan. Assoc. 2006, 72, 55-74. [CrossRef]

198. Dendup, T.; Astell-Burt, T.; Feng, X. Residential self-selection, perceived built environment and type 2 diabetes incidence: A longitudinal analysis of 36,224 middle to older age adults. Heal. Place 2019, 58, 102154. [CrossRef] [PubMed]

199. OECD and European Union. Indicators of Immigrant Integration 2015: Settling In; OECD Publishing: Paris, France, 2015; ISBN 9789264234024.

200. United Nations. World Social Report 2020: Inequality in a Rapidly Changing World; United Nations: New York, NY, USA, 2020; ISBN 9789211303926.

201. Cole, H.V.S.; Garcia Lamarca, M.; Connolly, J.J.T.; Anguelovski, I. Are green cities healthy and equitable? Unpacking the relationship between health, green space and gentrification. J. Epidemiol. Community Health 2017, 71, 1118-1121. [CrossRef]

202. WHO Regional Office for Europe. Urban. Green Spaces and Health: A Review of Evidence; World Health Organization: Copenhagen, Denmark, 2017.

203. Anguelovski, I. Tactical developments for achieving just and sustainable neighborhoods: The role of community-based coalitions and bottom-to-bottom networks in street, technical, and funder activism. Environ. Plan. C Gov. Policy 2015, 33, 703-725. [CrossRef]

204. Rigolon, A. Nonprofits and park equity in Los Angeles: A promising way forward for environmental justice. Urban. Geogr. 2019, 40, 984-1009. [CrossRef]

205. Rigolon, A.; Gibson, S. The role of non-governmental organizations in achieving environmental justice for green and blue spaces. Landsc. Urban. Plan. 2021, 205, 103970. [CrossRef]

206. Razani, N.; Niknam, K.; Wells, N.M.; Thompson, D.; Hills, N.K.; Kennedy, G.; Gilgoff, R.; Rutherford, G.W. Clinic and park partnerships for childhood resilience: A prospective study of park prescriptions. Heal. Place 2019, 57, 179-185. [CrossRef] [PubMed] 